\title{
Estrategias diplomáticas de la España del desarrollo en Sudamérica. Los escritores Giménez Caballero y Alfaro en Paraguay y Argentina
}

\author{
Diplomatic strategies in the Spain of developmentalism in \\ South America. The writers Giménez Caballero and Alfaro in \\ Paraguay and Argentina
}

Beatriz Figallo

Pontificia Universidad Católica Argentina (UCA)

IDEHESI/CONICET

Recibido: 27/09/2018

Aprobado: 15/11/2018

Resumen: Los lazos de la Hispanidad, utilizados como amplio nexo cultural dentro del espacio iberoamericano, contaron con instrumentos y vectores de transmisión que fueron útiles al régimen franquista en sus distintas etapas, y que entre fines de la década de 1950 y los años ' 70, sirvieron para rediseñar el vínculo español con la región con el propósito de llegar a convertirla en un área de expansión económica. Este artículo se centra en las actuaciones como diplomáticos de la España del desarrollo de Ernesto Giménez Caballero y José María Alfaro, dos falangistas históricos. Aquellos escritores, reconocidos "proveedores de retórica” del franquismo, se convertirán en eficaces valedores de negocios, que supieron acercarse a la dictadura de Alfredo Stroessner en Paraguay y a la sucesión de gobiernos cuasi democráticos y militares de la Argentina posperonista, para lograr la intensificación de las relaciones comerciales $\mathrm{y}$ de inversiones.

Palabras claves: Franquismo - Falangismo -dictadura paraguaya - Argentina posperonista

Abstract: The ties of Hispanity, used as a broad cultural nexus within the IberoAmerican area, had instruments and transmission vectors that were useful to the Franco regime in its various stages, and that between the late 1950 s and the ' 70 years, served to redesign the Spanish link with the region in order to turn it into an area of 
economic expansion. This article focuses on the actions of Ernesto Giménez Caballero and José María Alfaro, two historical phalangists, as diplomats of Spain. Those writers, recognized as "rhetoric providers" of Franco's regime, will become effective business champions, who knew how to approach the dictatorship of Alfredo Stroessner in Paraguay and the succession of quasi-democratic and military governments of postperonist Argentina, in order to achieve the intensification of commercial and investment relations.

Keywords: Francoism - Falangism - Paraguayan dictatorship - Post-peronism Argentina

\section{Palabras preliminares}

Tras lograr su aceptación plena en la Organización de las Naciones Unidas en 1955 y luego el respaldo de instituciones económicas globales para salir de las limitaciones de su autarquía e iniciar un urgente proceso de desarrollo, la España de Franco se dispuso a promover con América Latina una política exterior renovada. Si llevaba implícita la idea de conformar una comunidad de naciones unida por un conjunto de rasgos hispánicos, la ligazón comenzaría ahora a enfocarse en intereses económicos, que conllevaban la aspiración de rediseñar el vínculo a través de la expansión de sus inversiones. El plasma cultural que permitía vías de acercamiento entre España, su población emigrada -la económica, e incluso el exilio político- y distintos grupos dirigentes sudamericanos, se vería inficionado por la conveniencia de las relaciones económicas y la propagación de nuevos valores ligados a la modernización, que esta nueva etapa del régimen franquista ofrecería a los gobiernos de la región.

El presente trabajo parte de la consideración de la genealogía y el despliegue de ideas que sustentó aquel cambio de orientación exterior, para enlazarlo con los rápidos cambios que se sucederán, haciendo foco tanto en el molde ideológico que ayuda a explicar la proyección del franquismo en los países del Cono Sur, como en los vectores de traslación, ${ }^{1}$ singularizados en dos escritores que ejercieron largas misiones

\footnotetext{
${ }^{1}$ Sobre el análisis de los contextos de recepción/circulación de ideas y de sus vectores, dentro de la metodología propia de las "transferencias culturales", ver: JOYEUX-PRUNEL, Béatrice, "Les transferts culturels. Un discours de la méthode", Hypothèses, 2002, 1 ; ESPAGNE, Michel, "La notion de transfert culturel", Revue Sciences/Lettres [En ligne], 1 | 2013, mis en ligne le 01 mai 2012, consulté le 30 septembre 2016.
} 
representando a la "nueva España” en la Argentina y Paraguay. Se trataba de dos "camisas viejas" del falangismo, que no fueron solamente "proveedores de retórica”, sino eficaces valedores de negocios. Si los diplomáticos representaban -al decir de José María Pemán- "las naciones con cara",2 la elección de José María Alfaro y Ernesto Giménez Caballero para encarar este análisis, no se circunscribe a caracterizar sus "embajadas literarias", sino que busca reflexionar sobre sus funciones como observadores-participantes de la Sudamérica de mediados de los años cincuenta y principios de los ' 70 y cómo facilitadores de la aplicación de una renovada política exterior del régimen franquista, modelo que era autoritario en lo político y desarrollista en lo económico. Hacia 1955, con sus diferencias y matices, en la Argentina y Paraguay el franquismo contaba con sectores afines. Si los vínculos más importantes habían sido tejidos con el gobierno peronista, un contencioso económico impactó en los otrora estrechos vínculos de los tiempos del Protocolo Perón-Franco de 1948, congelándolos. En cambio, los dirigentes que detentaban el poder en Asunción no habían dejado de manifestar la admiración de grupos sociales y políticos paraguayos por el generalísimo. Así, empeñados en una vigilia constante en torno a la defensa ante cualquier ataque verbal o propagandístico contra la peculiaridad del régimen que gobernaba España y de los exiliados republicanos más reacios, el propósito exterior que guio a sus embajadas se dirigió a empatizar con sectores de poder y opinión que eran sensibles al espejo franquista, con el objetivo de contribuir a mejorar la inserción económica internacional de la nación que representaban. Se trata de un período de la política exterior de España que aún no ha sido investigado con detalle;3 no obstante, se están produciendo algunas contribuciones significativas, 4 en necesaria articulación con las crecientes aportaciones sobre las relaciones interamericanas de los años sesenta y setenta.

El núcleo de esta investigación se sostiene en el análisis de documentación

\footnotetext{
${ }^{2}$ La Vanguardia Española, Barcelona, 22 de febrero de 1969.

3 PARDO SANZ, Rosa María, "De puentes y comunidades: balance historiográfico sobre las relaciones con América Latina”, en Lorenzo DELGADO GÓMEZ-ESCALONILLA, Ricardo Martín de la GUARDIA y Rosa PARDO SANZ (eds.), La apertura internacional de España. Entre el franquismo y la democracia, 1953-1986, Madrid, Ediciones Sílex, 2016. Aludiendo a temas a estudiar, Pardo Sanz señala en página 148: "un caso interesante podría ser el de Paraguay en la etapa de Stroessner (1954-1989), un autócrata admirador de Franco, quien envió a Ernesto Giménez Caballero como embajador".

4 CAÑELLAS MÁS, Antonio (coord.), La tecnocracia hispánica. Ideas y proyecto político en Europa y América, Gijón, Ediciones Trea, 2016; FIGALLO, Beatriz (ed.), Desarrollismo, franquismo y neohispanidad. Historias conectadas entre España, América Latina y Argentina, Buenos Aires, Teseo, 2018.
} 
inédita y hoy de vedado acceso del Archivo del Ministerio de Asuntos Exteriores de España, que estaba resguardada en el Palacio de Santa Cruz, en el corazón del Madrid de los Austrias. Entre 2010 y 2012 el gobierno español decidió primero la restricción de su acceso y posteriormente su dispersión, pasando los fondos históricos del siglo XX al Archivo General de la Administración de Alcalá de Henares, sin que a la fecha se hayan librado nuevamente a una consulta amplia. Parte de una generación de historiadores de las relaciones internacionales que pudieron abrevar de aquella información valiosa para tesis doctorales, artículos y libros y del contacto con investigadores que frecuentaban desde los años ' 80 su sala de consulta, distintos proyectos de investigación solventados por la Fundación Carolina, la Universidad Autónoma de Madrid, el CONICET, la Agencia Nacional de Promoción Científica y Tecnológica de Argentina y la Universidad Católica Argentina, me permitieron que entre 2004 y 2010 permaneciera largos períodos recopilando documentación posterior a 1955, ahora inaccesible. Este artículo es otro producto intelectual más de aquellas campañas. 5 Se trata de un bagaje que permite reconstruir historias bilaterales, digamos diplomáticas -sin descartar que para abordarlas, recurramos en próximos trabajos a los fondos documentales de los archivos oficiales de la Argentina y Paraguay, así como de instituciones culturales y repositorios privados-, enmarcadas dentro de presupuestos clásicos y hasta renovadores de los enfoques que propiciaron Pierre Renouvin, Jean Baptiste Duroselle, Robert Frank, ${ }^{6}$ pero a la vez habilita para encarar el tema bajo el prisma de una perspectiva transnacional, donde se observan interrelaciones que cuestionan las fórmulas automáticas de "difusión/divulgación" entre un centro emisor -España- y una o más periferias -Argentina, Paraguay, Cono Sur-, optando más bien por atender procesos de irradiación, como señala Weinsten.7 La cuestión es reconocer los intercambios y la circulación de ideas, personas, productos culturales, tradiciones, así como a las transferencias, las intersecciones y las conexiones entre espacios geográficos, donde se repara en redes, procesos,

\footnotetext{
5 Ver, además de las varias contribuciones citadas en este trabajo, por ejemplo: FIGALLO, Beatriz. Argentina-España. Entre la pasión y el escepticismo. Buenos Aires, Teseo, 2014; "Sociabilidad y exilio. Perón entre los españoles del franquismo, 1960-1973". Res Gesta, 53, 2017, y "Desarrollo y estado de derecho administrativo. El modelo del nuevo hispanismo en la Argentina posperonista", en FIGALLO, Beatriz (ed.), Desarrollismo, franquismo y neohispanidad, cit..

${ }^{6}$ FRANK, Robert (dir.). Pour l'histoire des relations internationales. Paris, Presses Universitaires de France, 2012.

7 WEINSTEIN, Barbara. "Pensando la historia más allá de la nación: la historiografía de América Latina y la perspectiva transnacional". Aletheia, 2013, 3, nº 6 .
} 
instituciones, movimientos y flujos que se extienden más allá de las naciones. ${ }^{8}$ Por ello, también la producción literaria y periodística de los "embajadores escritores" es directa fuente del trabajo, así como un amplio rastreo de bibliografía que trata de conectar y hacer convergir el saber disyunto en numerosos trabajos. Organizamos el texto presentando las características que constituyen el magma cultural e ideológico tradicional que sirvió de soporte a la acción exterior franquista en el Cono Sur, los cambios que la "Nueva España" impulsada al desarrollo introducirá en sus relaciones con la región, para luego poner en clave comparativa los desempeños diplomáticos de sus embajadores escritores.

\section{La base compartida de una cultura hispánica católica y de orden}

Elegir la palabra hispanidad9 para abordar y explicar los vínculos iberoamericanos en parte importante del siglo XX no es azaroso, sino bastante obvio a esta altura de las investigaciones. Trayectorias y argumentaciones, ${ }^{10}$ permiten considerarlo como el nexo cultural principal en el que se sostuvo la presencia de España en América. Cuando ya el término anticuado relacionado con los modismos propios de la lengua española se fue dotando de nuevos significados, ${ }^{11}$ una variante

${ }^{8}$ FAZIO VENGOA, Hugo. "La historia global y su conveniencia para el estudio del pasado y del presente". Historia Crítica, 2009; IRIYE, Akira. Global and Transnational History: The Past, Present, and Future. Basingstoke, Palgrave Macmillan, 2013. Una recapitulación importante y actualizada sobre esta perspectiva historiográfica en: HAUSBERGER, Bernd y PANI, Erika, en la presentación del Dossier sobre Historia Global, Historia Mexicana, LXVIII, 1, julio-septiembre, 2018.

9 Aunque los diccionarios han habilitado a utilizar como sinónimo de hispanidad a hispanismo, un análisis lexicológico primero y otro ideológico después, permiten admitir cierta confusión, producto tanto de la interpenetración de los términos como de la misma evolución histórica de su uso.

10 Ver: GONZÁLEZ CALLEJA, Eduardo y LIMÓN NEVADO, Fredes, La Hispanidad como instrumento de combate, Madrid, CSIC, 1988; ARENAL, Celestino del, Política exterior de España y relaciones con América Latina. Iberoamericanidad, europeización y atlantismo en la política exterior española, Madrid, Fundación Carolina-Siglo XXI, 2011, pp. 21-33; MARCILHACY, David, "La Hispanidad bajo el franquismo. El americanismo al servicio de un proyecto nacionalista", en Xosé M. NÚÑ̃EZ SEIXAS y Stéphane MICHONNEAU (eds.), El imaginario nacionalista español en el franquismo, Madrid, Casa de Velázquez, 2014, p. 73-102. En relación con los países latinoamericanos, aportes que merecerían no obviarse son: PÉREZ MONTFORT, Ricardo, Hispanismo y Falange. Los sueños imperiales de la derecha española y México, México, FCE, 1992; GONZÁLEZ DE OLEAGA, Marisa, "Panamericanismo e hispanidad en la política exterior argentina de la Segunda Guerra Mundial. La confrontación política en la creación de identidades colectivas", EIAL, 5, N. 1, 1994; JARA HINOJOSA, Isabel, De Franco a Pinochet: el proyecto cultural franquista en Chile 1936-1980, Santiago, Universidad de Chile, 2006; GONZÁLEZ CALLEJA, Eduardo, "El Hispanismo autoritario español y el movimiento nacionalista argentino: balance de medio siglo de relaciones políticas e intelectuales (1898-1946)", Hispania, 2007, mayo-agosto, núm. 227.

${ }^{11}$ Una idea de hispanidad persistente fue difundida por Ramiro de Maeztu, a través de su obra Defensa de la Hispanidad, de asidua lectura por años en círculos conservadores sudamericanos. Embajador de la dictadura del general M. Primo de Rivera en la Argentina entre 1928-1930, la distinguió del concepto de raza, para definirla como aquella que esta "constituida por el habla y por la fe, que son espíritu y no por las oscuridades protoplasmáticas”, en MAEZTU, Ramiro de, Defensa de la Hispanidad, Buenos 
prevalente se abrió camino entre las décadas de 1920 y 1930, en el contexto de internacionalización de las políticas de la Iglesia católica romana ${ }^{12} \mathrm{y}$ de la expansión de su influencia en sectores de la sociedad argentina, de su difusión por religiosos españoles ${ }^{13}$ y de los contactos con la jerarquía católica paraguaya. Aunque no fuera propiedad exclusiva de los grupos católicos o conservadores y nacionalistas, el término hispanidad fue desdibujándose con los años, pero fue portador de sentidos que atraviesan las relaciones del franquismo con América Latina. En ese largo recorrido, la categoría "hispanidad" fue útil para adherir y alegar en favor del modelo español diferenciado de los nazi-fascismos derrotados en 1945-, reivindicar la idea de neutralidad y figurar al franquismo "como el movimiento político que superará los peligros del liberalismo y el marxismo", ${ }^{14}$ exaltando los valores tradicionales hispánicos para reconstruir una "identidad de destino". De forma sostenida, muchos de esos postulados se difundieron a través de la prensa, la producción literaria y los vínculos universitarios que conectaban españoles y latinoamericanos. De las depuradas universidades españolas de la posguerra civil, donde se había impuesto, como una suerte de restauración, el espíritu cristiano, ${ }^{15}$ se reivindicaba la grandeza de la nación como eje espiritual del mundo hispánico, ${ }^{16}$ y se exigía juramento de fidelidad a los llamados principios del Movimiento Nacional y de la Falange, llegarían profesores y catedráticos a recorrer la región, para conferenciar, dar clases y escribir en diarios, suplementos culturales y revistas. Desde España, será el Instituto de Cultura Hispánica (ICH) el instrumento por antonomasia de la vinculación que podía brindar lo cultural,

\footnotetext{
Aires, Librería Huemul, 1986, p. 71. Un análisis atractivo sobre la genealogía y el significado del término "hispanidad" en Maeztu, en JIMÉNEZ TORRES, David, Ramiro de Maeztu and England. Imaginaries, realities and repercussions of a Cultural Encounter, Tamesis, Woodbridge, 2016, p. 148 y ss.

12 RODRÍGUEZ-LAGO, José Ramón, "La clave Cortesi. La política vaticana en la República Argentina (1926-1936)”, Historia Contemporánea, 55, 2017.

13 VIZCARRA, Zacarías de, “Origen del nombre, concepto y fiesta de la hispanidad”, El Español, Madrid, 7 de octubre de 1944. Ver TATEISHI, Hirotaka, "Zacarías de Vizcarra y la vocación de América: Apuntes sobre la Hispanidad y el nacional-catolicismo", The Mediterranean Studies Group Hitotsubashi University, 2004-03.

14 FARES, María Celina, "Diferencias y convergencias en los hispanismos mendocinos. A propósito del sesquicentenario", en Dossier: El nacionalismo argentino durante la $2^{0} \mathrm{mitad}$ del siglo XX. historiapolítica.com - http://historiapolitica.com/datos/biblioteca/fares2.pdf [Consultado en línea: 1 de abril de 2013].

15 Dice PULPILLO LEIVA, Carlos, Orígenes del franquismo: la construcción de la nueva España (19361941), Tesis doctoral, Universidad Rey Juan Carlos, Madrid, 2013, Tomo II en página 972, que entrevistado Franco en el Noticiero de España, Núm. 13, 27 de noviembre de 1937, éste afirmó: "No hará falta Universidad católica porque todas nuestras Universidades serán católicas y en ellas habrá una enseñanza superior religiosa de carácter filosófico".

${ }^{16}$ DELGADO GÓMEZ ESCALONILLA, Lorenzo, Imperio de papel. Acción cultural y política exterior durante el primer franquismo, Madrid, CSIC, 1992, p. 243.
} 
política que se completaría con las facilidades para hospedarse que brindaría a los estudiantes el Colegio Mayor Nuestra Señora de Guadalupe de Madrid, con la Universidad de Sevilla y el grupo de historiadores que crearon la Escuela de Estudios Hispanoamericanos y su extensión, los cursos de verano de La Rábida, en Huelva. Aun sometida a grandes estrecheces, España se esforzó por difundir la existencia de una vida cultural que procuraba rehacerse, propiciando publicaciones, distribuyendo libros, organizando eventos académicos, desarrollando una política de concesión de becas a universitarios y jóvenes profesionales latinoamericanos para que continuaran sus estudios o investigaran en sus archivos y bibliotecas, hospedándose en sus colegios mayores. ${ }^{17}$ Desde 1951 se incentivaron las creaciones de institutos en América, con el objetivo de formar una conciencia hispánica común, que las filiales locales contribuirían a consolidar. Con la evolución del régimen, se desarrollaría un pensamiento hispanista de factura nacional, expurgándolo de los componentes franquistas más evidentes. ${ }^{18}$

El concepto franquista de Hispanidad también recogió el componente religioso. Sumado a las redes de relaciones que conformaron los católicos franquistas acercándose a sus correligionarios latinoamericanos a través de asociaciones seglares y religiosas, ${ }^{19}$ distintas órdenes españolas dedicadas a la educación o a la atención del colectivo de emigrantes, constituyeron una influencia tangible en la sociedad sudamericana. Con ironía proclamó el escritor Agustín de Foxá, diplomático en Buenos Aires entre 1947 y 1950, "seguimos constituyendo el primer país del mundo en exportación de... sacerdotes”, 20 estimándose que para mediados de la década del cincuenta casi el $50 \%$ de los sacerdotes en Iberoamérica, unos 12.00o, eran

\footnotetext{
${ }_{17}$ POZO REDONDO, Felipe del, "Un aspecto de la estrategia cultural franquista hacia América Latina: la Universidad Hispanoamericana de La Rábida (1943-1974)", en Francisco A. RUBIO DURÁN-R. DELIBES MATEOS (eds.), Espacio y poder en América Latina. Actores y escenarios históricos en los contextos de dominación, Sevilla, Aconcagua Libros, 2010, p. 204. Ver también: DELGADO GRANADOS, Patricia, "La Escuela de Estudios Hispanoamericanos de Sevilla: Proceso de configuración de su identidad", Historia Caribe, Vol. 4, Nro. 12, 2007.

${ }^{18}$ JARA HINOJOSA, Isabel, De Franco a Pinochet, cit., p. 234.

19 ESCUDERO, María, El Instituto de Cultura Hispánica, Madrid, Mapfre, 1994, p. 108; SANCHEZ RECIO, Glicerio (coord.), La Internacional Católica. Pax Romana en la política europea de posguerra, Madrid, Biblioteca Nueva, 2005; MUÑOZ SORO, Javier, "Joaquín Ruiz-Giménez o el catolicismo total (Apuntes para una biografía política e intelectual hasta 1963)", Pasado y Memoria. Revista de Historia Contemporánea, 5, 2006, p. 265.

20 FERNÁNDEZ CANTOS, José Luis, “¿Hacia dónde va Iberoamérica?”, Revista de Estudios Políticos, 106, 1959, p. 222.
} 
españoles. ${ }^{21}$ Aquel tradicional valimiento de la España católica se vería además reforzado por otros grupos religiosos. La actuación más novedosa vendría con la llegada a la Argentina en 1950 de la institución secular del Opus Dei, ${ }^{22}$ año en el que también dieron inicio las actividades en Chile, seguidas en 1951 en Colombia y Venezuela, 1953 en Perú, 1956 en Uruguay y 1962 en Paraguay. ${ }^{23}$ A principios de los años sesenta, asimismo con impronta española, renovarían la religiosidad de la región los "Cursillos de Cristiandad", 24 prácticas de retiros espirituales según el modelo jesuita introducidos por jóvenes católicos que habían vivido en España, difundidos por laicos españoles.

\section{Hispanidad y falangismo por el Cono Sur}

La Falange española -el partido único fundado en 1933 que heredó Franco-25 se apropió de aquel concepto de hispanidad, católico y tradicionalista. Y aunque, como han explicado Pardo Sanz y González-Calleja, ${ }^{26}$ pasada la guerra civil las aspiraciones de expansión del falangismo no prevalecieron sobre órganos e instancias administrativas propias de la política exterior española, si se registró un acercamiento con América Latina, donde actuó como soporte propagandístico del franquismo entre la colonia española y grupos locales afines, basado en un programa de orden, anticomunista y católico. Diseminados en artículos, capítulos, ponencias y alguna tesis doctoral, ${ }^{27}$ algo se viene escribiendo sobre la expansión del falangismo por el Cono Sur,

\footnotetext{
${ }^{21}$ Ver LAMBERTI, Alejandro, "Iglesia y democracia en la Argentina de los '60 y los '9o", en ESTEVEZ, Alejandro M., Proyecto: Estado, Sociedad y cultura democrática en la reforma del estado argentino, Buenos Aires, UCA-Instituto para la Integración del Saber, 2002, p. 153 [consulta en línea 25 de noviembre de 2015]

${ }^{22}$ GÓMEZ PÉREZ, Rafael, El franquismo y la Iglesia. Madrid, 1986, p. 252.

23 También en FUENMAYOR, Amadeo de - GÓMEZ-IGLESIAS, Valentín - ILLANES, José Luis, El itinerario jurídico del Opus Dei. Historia y defensa de un carisma. Pamplona, Eunsa, 1989; VÁZQUEZ DE PRADA, Andrés, El fundador del Opus Dei. III. Los caminos divinos de la tierra, Madrid, Rialp, 2003.

${ }^{24}$ De regreso en España, Zacarías de Vizcarra fue nombrado consiliario general de Acción Católica Española y primer consiliario de los Cursillos de Cristiandad.

${ }^{25}$ Ver THOMÀS, Joan María, Lo que fue la Falange: La Falange y los falangistas de José Antonio, Hedilla y la Unificación. Franco y el fin de la Falange Española de las JONS, Barcelona, Plaza \& Janés, 1999; ELLWOOD, Sheelagh M., Historia de la Falange Española, Barcelona, Crítica, 2001.

${ }^{26}$ PARDO SANZ, Rosa María, "Hispanoamérica en la política nacionalista, 1936-1939", Espacio, Tiempo y Forma, Serie V, H. Contemporánea, t. V, 1992, p. 228. También GONZÁLEZ CALLEJA, E., "El servicio exterior de Falange y la política exterior del primer franquismo: consideraciones previas para su investigación”, Hispania, LIV/1, n. 186, 1994.

${ }^{27}$ Por ejemplo, TESSADA SEPÚLVEDA, Vanessa, Las estrategias de proyección internacional de la Sección Femenina española hacia Latinoamérica y su recepción en Chile (1937-1977), Tesis doctoral, Universidad de Valladolid, 2017, investigación que analiza las políticas culturales-diplomáticas del
} 
aunque pocas veces escapa visiones casuísticas, siendo una excepción para ese panorama, el importante libro de Carlos Zubillaga referido a la actuación de la Falange en el Uruguay. ${ }^{28}$ Para el resto de los países, los estudios navegan entre la carencia y la sobreabundancia. En el contexto de una reducida colonia española en el Paraguay -por entonces envuelto en la crisis bélica con Bolivia y en las tensiones de las negociaciones pacificadoras-, con un rápido pronunciamiento del ministro plenipotenciario Felipe García-Ontiveros, quien "durante la Cruzada defendió en América la causa de España”,29 no conocemos trabajos específicos sobre la influencia de la primigenia Falange española allí, aunque sí investigaciones valiosas referidas a la sintonía de los gobiernos de la posguerra del Chaco con los nazi-fascismos europeos en general.30 Del despliegue inicial de la Falange en la Argentina hay referencias en numerosos trabajos $3^{31}$ e incluso una descriptiva crónica, ${ }^{22}$ que aunque revestida de cierto ánimo proselitista, ofrece información de utilidad. Llegado el peronismo puede aceptarse que los falangistas autóctonos "contribuyeron a un tópico imitativo y superficial del ejemplo español que perduró durante muchos años”, aunque Zuleta Álvarez los considera, "políticamente inocuos y sin significación intelectual".33 Sin embargo, ciertos indicios -no totalmente indagados a la fecha- muestran que algunas influencias

franquismo, especialmente las realizadas por la Sección Femenina de Falange Española Tradicionalista y de las JONS.

${ }_{28}$ ZUBILLAGA, Carlos, Una historia silenciada. Presencia y acción del falangismo en Uruguay (19361955), Montevideo, Ediciones Cruz del Sur, 2015.

${ }_{29} A B C$, Madrid, 5 de febrero de 1955.

3o SEIFERHELD, Alfredo, Nazismo y fascismo en el Paraguay. Vísperas de la II Guerra Mundial. Gobiernos de Rafael Franco y Félix Paiva. 1936-1939, Asunción, Editorial Histórica, 1985; RODRÍGUEZ ALCALÁ, Guido, Ideología autoritaria, Asunción, RP Ediciones 1987.

${ }^{31}$ Ver, por ejemplo, DELGADO GÓMEZ-ESCALONILLA, Lorenzo y Marisa GONZÁLEZ DE OLEAGA. "La dinámica franquismo/oposición en Argentina: un ensayo de interpretación (1936-1950)", en Javier TUSELL, Abdón MATEOS y Alicia ALTED (coords.). La oposición al régimen de Franco. Estado de la cuestión y metodología de la investigación; Tomo I, Vol. 2, Madrid, UNED, 1990; QUIJADA, Mónica, Aires de República, Aires de Cruzada. La Guerra Civil Española en la Argentina. Barcelona, Sendai Ediciones, 1991; FERREYRA, Alejandra Noemí, "La acción propagandística a favor del Franquismo durante la Guerra Civil Española: la actuación de Juan Pablo Lojendio en Buenos Aires (1936-1939)", Páginas, Vol. 8, N. 16, 2016. Afirma Mariela RUBINZAL en su tesis doctoral titulada: El nacionalismo frente a la cuestión social en Argentina [1930-1943]: Discursos, Representaciones y prácticas de las derechas sobre el mundo del trabajo [en línea]. Universidad Nacional de La Plata. Facultad de Humanidades y Ciencias de la Educación. Disponible en: http://www.memoria. fahce.unlp.edu.ar/tesis/te.450/te.450.pdf, p. 123, que en 1938, "según el informe de la inteligencia norteamericana la Falange española contaba con 3.000 miembros en todo el país, la mayoría de ellos eran argentinos nacidos en el país".

${ }^{2}$ JEREZ RIESCO, José Luis. Voluntad de Imperio. La Falange en Argentina. Barcelona, Ediciones Nueva República, 2007.

33 ZULETA ÁLVAREZ, Enrique. "España y el nacionalismo argentino”. Cuadernos del Sur, № 23/24, 1993, p. 28. 
se permearon hasta el peronismo.34 Ya en 1943 José Figuerola -funcionario de la dictadura de Primo de Rivera exiliado en Buenos Aires e imbuido de ideas sociales de cuño falangista- comenzó a trabajar en el Departamento de Nacional del Trabajo, y allí estaba cuando Juan Perón se hizo con su control.35 Enrique Pavón Pereyra, "joven hispanista ocupado en estudiar documentos sobre la Guerra Civil Española”, ${ }^{6}$ que había adherido al naciente movimiento peronista desde que el coronel era secretario de Trabajo,37 arribó a Madrid en compañía del designado agregado obrero de la embajada argentina, Ramón Vera, en los meses previos a la visita a España de Eva Duarte, la primera dama. Cercano a los grupos del revisionismo histórico argentino, comenzaría una tarea de difusión en la Argentina de la figura del fundador de la Falange: en el décimo aniversario de su muerte, publicó Testimonios de José Antonio y luego Confesiones de José Antonio.38 Posteriormente en la Editora Nacional de Madrid apareció su libro De la vida de José Antonio.39 En el complejo mundo de las cercanías peronismo-falangismo, Cerrano y Peñalba advierten que "la Falange rechaza que se la identifique con la derecha, ya que pretende presentarse como una tercera vía entre la izquierda y la derecha que logre desarrollar el potencial y la esencia de la nación española”. 40 Tras la caída de Perón, la admiración por el falangismo dentro del violento 34 Si los falangistas reconocían en Perón el reflejo de las ideas joseantonianas, el falangista José Antonio
Girón de Velasco, ministro de Trabajo entre 1941 y 1957, era conocido como el "Perón español”. Amigo
de José Antonio Primo de Rivera, calificado como un "utópico fascista", sería considerado inspirador de
la política que el líder justicialista aplicó en la Argentina, ver RODRÍGUEZ PUÉRTOLAS, Julio,
Literatura fascista española. Volumen I, Historia. Madrid, 1986, p. 779; ZAFRILLA TOBARRA,
Ricardo, Universidades laborales. Un proyecto educativo falangista para el mundo obrero (1955-
1978): aproximación histórica, Cuenca, Ediciones de la Universidad de Castilla-La Mancha, 1998, p. 75.
35 REIN, Raanan, "Los hombres detrás del Hombre: la segunda línea de liderazgo peronista", Araucaria.
Revista Iberoamericana de Filosofía, Política y Humanidades, N. ${ }^{\circ}$ 19, primer semestre 2008, p. 88 y
ss.

${ }^{36}$ La Vanguardia Española, Barcelona, 18 de febrero de 1947.

37 Pavón Pereyra conoció a Perón cuando investigaba historia argentina en la colección de periódicos de la Legislatura de Buenos Aires (en Plaza de Mayo), y aquel instaló allí la sede de la Secretaría de Trabajo y Previsión. Considerado el biógrafo oficial de Perón escribió: Perón, el conductor de América (1950) y Perón. Preparación de una vida para el mando (1895-1942) (1953), precuela de numerosas obras escritas durante los años del exilio peronista en España.

${ }^{8}$ Una interpretación atendible sobre la imagen del falangismo original modificado por el franquismo que transmitió el peronismo, la brinda BERNETTI, Jorge Luis, "De la Falange Española a la Alianza Libertadora Nacionalista y el Movimiento Nacionalista Tacuara", Pensamiento de los confines, 1, segundo semestre de 1998. Ver también: CAMARASA, Jorge, La enviada. El viaje de Eva Perón a Europa, Buenos Aires, Planeta, 1998. En referencia a los vínculos del posperonismo con el falangismo, CERRANO, Carolina, "El filo-peronismo falangista. 1955-1956", Ayer, N. ${ }^{\circ}$ 96, 2014.

39 Compartiendo con Perón el exilio español, Pavón Pereyra retomaría su dedicación a la figura máxima del falangismo en libros que publicó con el militante falangista Agustín del Río Cisneros: Últimos hallazgos de escritos y cartas de José Antonio (1962); Los procesos de José Antonio (1963); José Antonio abogado (1963, con prólogo de Raimundo Fernández-Cuesta); José Antonio íntimo. Epistolario y textos biográficos (1964); Textos biográficos y epistolarios: José Antonio íntimo (1968).

$4^{\circ}$ CERRANO, Carolina y PEÑALBA, Mercedes, "La OMU y la Conferencia Internacional de dirigentes 
grupo juvenil nacionalista Tacuara, conformado en 1957, es señalado por recientes investigaciones. ${ }^{41}$ Entre otros historiadores, Goebbel remarca el influjo falangista que llegaría a hacer confluir en el 20 de noviembre la conmemoración del fusilamiento de José Antonio con la batalla de la Vuelta de Obligado que las fuerzas del gobernador de Buenos Aires Juan Manuel de Rosas entablaron con las flotas de Francia y Gran Bretaña en $1845 .^{42}$

\section{La "Nueva España" desarrollista y modernizante: sus diplomáticos en el Cono Sur}

Mediando la década del '50, España compartía con gran parte de América Latina una situación económica apremiante: el Banco Mundial y el FMI lo señalaban como un país técnicamente en bancarrota. Se imponía un cambio, que comenzó a consumarse con la renovación del gabinete franquista en febrero de 1957, siendo lo más significativo los nombramientos en los ministerios económicos. La prioridad se le concedió a las reformas administrativas, técnicas y financieras, mientras las de carácter político -admitiéndose una futura monarquía- estaban supeditadas al deseo de permanencia vitalicia de Franco en el poder.43 Si se descarta cualquier coordinación política previa, la adscripción del grupo principal de funcionarios y ministros -los tecnócratas- al Opus Dei, le aseguraba al régimen un elenco de un catolicismo acendrado -aunque diferente, no clerical-, un talante más moderno, con una formación profesional rigurosa y especializada.44 Las investigaciones de Sesma Landrín señalan que tecnócratas y falangistas, principales "familias" ideológicas del régimen entonces, mostraban tanto divisiones internas como disponibilidad para tender lazos personales

universitarios de junio de 1955 vista desde la delegación española del SEU”, Revista electrónica de Fuentes y Archivos, Número 5, 2014, p. 199.

${ }^{41}$ CAMPOS, Esteban, "¿De fascistas a guerrilleros? Una crítica a la historiografía del movimiento nacionalista Tacuara y sus derivas hacia la izquierda peronista en la Argentina”, Revista Tiempo Histórico, $\mathrm{N}^{\circ}$ 13, julio-diciembre 2016.

42 GOEBBEL, Michael, La Argentina partida. Nacionalismos y políticas de la historia, Buenos Aires, Prometeo, 2013, p. 176. Ver también GALVÁN, María Valeria, "Discursos de los organismos de inteligencia argentinos sobre el Movimiento Nacionalista Tacuara en el marco de la primera Guerra Fría”, Antíteses, vol. 2, n. 4, jul.-dez. de 2009;

43 RIQUER, Borja de, La dictadura de Franco, en Josep FONTANA-Ramón VILLARES, Historia de España. Volumen 9, Madrid, Critica, 2010, pp. 421-423.

44 Ver ORELLA, José Luis, "El origen de la derecha tecnocrática española y sus consecuencias", en Ernesto BOHOSLAVSKY-Olga ECHEVERRÍA (comps.), Las derechas en el Cono Sur, siglo XX. Actas del tercer taller de discusión. Los Polvorines, 2013. 
y favorecer mutuas concesiones políticas y colaboraciones sectoriales. 45

La puesta en marcha de una política propiciada por los organismos económicos internacionales, un programa enérgico de desarrollo y un "pequeño” Plan Marshall para ella sola,46 le permitirían a España superar, esforzadamente, un panorama de desmesurada inflación, desempleo, escasez de reservas y negativa balanza de pagos, protagonizando en poco tiempo un crecimiento notable. No fue un proceso inocuo para su sociedad, pues significó también la emigración masiva de miles de trabajadores a países desarrollados de Europa y el aumento de represión ciudadana y de tensiones sociales. Conforme nuevas generaciones manifestaban diversas formas de rechazo a los principios con que el franquismo había sujetado a España, se multiplicaban los gestos de activismo político y de enfrentamientos al régimen que se fueron extendiendo entre obreros y estudiantes, a pesar del control que se venía ejerciendo sobre la universidad, con algunas medidas democratizadoras y el retroceso de la influencia falangista. 47 Ello no significaba que no persistiera un importante consenso en torno de Franco, vía el convencimiento, la conformidad o el sometimiento de la oposición interna y la vigilancia de la externa, pero además de vigilar las críticas internacionales a la institucionalidad franquista, se reconocía que era urgente mejorar la situación material del país. Recuerda Minardi que en el mensaje de fin de año de 1958, Franco habla de la política como misión dotada de connotaciones religiosas, no meramente como ejercicio del poder. De esta forma, renacimiento espiritual ya no se oponía a la mejora económica sino, por el contrario, la hacía necesaria. 48

En los años más duros del ostracismo franquista, la Falange había sido señalada

\footnotetext{
45 SESMA LANDRIN, Nicolás, Camino a la institucionalización. La pugna entre Falange y los sectores en torno al proceso de reforma administrativa de finales de los años cincuenta, Seminario de Historia, Instituto Universitario José Ortega y Gasset-Curso 2008-2009, Madrid, Documento de trabajo 2009/2, p. 5 .

${ }^{46}$ MUNS ALBUIXECH, Joaquín, “España y el Fondo Monetario Internacional (FMI)”, Economistas, No 90, 2001.

47 MESA, Roberto, ed., Jaraneros y alborotadores. Documentos sobre los sucesos estudiantiles de febrero de 1956 en la Universidad Complutense de Madrid, Madrid, UCM, 2006, 2da. Edición, p. 14, quien remite a los trabajos de Juan Manuel Farga, Universidad y democracia en España. Treinta años de lucha estudiantil (1969) y LIZCANO, Pablo, La generación del 56. La Universidad contra Franco (1981). Ver también: ABELLÁN, José Luis, "La muerte de Ortega y Gasset y la generación de 1956", Triunfo, Madrid, 23 de junio de 1979.

48 MINARDI, Adriana, "El franquismo a la luz de sus metáforas", Cultura, Lenguaje y representación, Vol. 9, 2011, p. 126. También SESMA LANDRIN, Nicolás, "Franquismo, ¿Estado de Derecho? Notas sobre la renovación del lenguaje político de la dictadura durante los años 6o", Pasado y Memoria. Revista de Historia Contemporánea, 5, 2006.
} 
como una organización de propaganda patrocinada por un régimen marcado por sus connivencias nazi-fascistas, y por tanto desacreditada e incluso prohibida en muchos países latinoamericanos. 49 Eso no fue óbice para que antiguos falangistas ocuparan algunas sedes diplomáticas americanas.50 Destaca la figura de José María de Areilza, quién sería designado embajador en la Argentina de Perón en 1947 -que luego alcanzaría gran proyección política al ocupar las embajadas de Washington y Paríscuando era un hecho "la precaria disponibilidad de contactos [de] nuestra apretada y solitaria situación de lazareto"..$^{11}$ Después de algunos contratiempos,52 la diplomacia franquista echó mano para ocupar embajadas de personalidades con diversas orientaciones políticas -de la derecha, monárquicos, católicos, funcionarios de carrera adictos al régimen-,53 aunque durante la gestión ministerial de Alberto Martín Artajo (1945-1957) se fueron desplazando a los falangistas de los cargos de peso en Exteriores -tanto como a militares- para dar preponderancia a los católicos. 54

Sin embargo, de entre los que tenían pedigrí falangista, algunos fueron convocados para cumplir funciones diplomáticas en Sudamérica, incluso con el propósito de colaborar en un necesario "lavado de cara del régimen”.55 Así como el

\footnotetext{
49 Ver FIGUEREDO CABRERA, Katia, "Carlos Prío Socarrás, Fulgencio Batista, Francisco Franco: la escalada hacia una consolidación 'fraterna' (1948-1958)", Revista Illes I Imperis, 12, 2009, p. 52-53.

${ }^{5} \mathrm{El}$ miembro fundador y jefe nacional de Falange Española de las JONS Raimundo Fernández-Cuesta fue embajador en Río de Janeiro, entre 1940 y 1942. El triunfo de los aliados en 1945 no resultó el momento más oportuno para repetir designación en Brasil, esta vez en la figura de Eduardo Aunós, quien sería repudiado precisamente por su falangismo, retirándosele el plácet diplomático, en BRANCATO, Sandra, "O Caso Aunós na versão da grande imprensa carioca e do Itamaraty", Estudos Ibero-Americanos, v. XXXIII, n. 2, dezembro 2007.

${ }^{51}$ AREILZA, José María de, Memorias exteriores. 1947-1964, Barcelona, Planeta, 1984, p. 19.

$5^{2}$ Además del incidente con la designación de Aunós, Gran Bretaña no concedió el plácet para la designación como embajador de José María Castiella, autor junto con Areilza del libro Reivindicaciones de España (1941).

53 Ver MORENO CANTANO, Antonio César (coord.), Cruzados de Franco. Propaganda y diplomacia en tiempos de guerra (1936-1945), Gijón, Trea, 2013.

54 FERNÁNDEZ FERNÁNDEZ-CUESTA, Juan Manuel, "La información al servicio de la política exterior. La creación de la oficina de información diplomática, respuesta del franquismo al aislamiento internacional (1945-1950)", Revista Internacional de Historia de la Comunicación, N. ${ }^{\circ}$ 1, Vol. 1, año 2013 p. 151, quien señala que "los diplomáticos de Franco se integraron en la Falange sólo minoritariamente. Mantuvieron su poder mientras Serrano Suñer conservó su gran influencia ante el jefe del Estado. Pero después fueron cediendo sus puestos, primero ante militares de tendencia anglófila y, más tarde, ante representantes del catolicismo político". Eran momentos en que la significación oficial del falangismo se atemperó, quedando restringido a pocos ministerios aunque continuó con su prédica en ámbitos laborales y sus demandas de mayores dosis de justicia social, en Monique DUPUICH DA SILVA y José María SÁNCHEZ DIANA, "Historia de una revista. Consideraciones sobre "Escorial", Boletín de la Institución Fernán González, 44, 165, 2º sem. 1965, p. 737.

55 AGUILERA SASTRE, Juan, "Entre dos exilios. Rivas Cherif y García Lorca”, Archivum, Tomo 63, 2013, p. 33 .
} 
franquismo se estaba transformando, muchos falangistas de la primera hora supieron adaptarse al nuevo ciclo de la dictadura. José María Doussinague, funcionario de carrera del Ministerio de Asuntos Exteriores especializado en América Latina,56 ocupará la embajada en Santiago de Chile entre 1950 y 1960. Hombre de la cultura, autor de numerosos libros dedicados a la España del siglo XVI, designado miembro correspondiente de la Academia Chilena de la Historia, había llegado a Santiago en 1949 como encargado de negocios con el objetivo político de lograr la normalización de las relaciones hispano-chilenas, deterioradas desde el fin de la guerra civil. Por entonces el gobierno de Gabriel González Videla se resistía a restablecer relaciones con el régimen franquista, pero Doussinague logró el envío de un embajador chileno a Madrid, siguiendo el reconocimiento norteamericano.57 Ese mismo año de 1950, la visita de un grupo de Coros y Danzas de la Sección Femenina de Falange en Chile lo llevó a escribirle a Pilar Primo de Rivera una carta narrándole la experiencia, "tan voluntariosa y cargada de retórica franquista que fue publicada en facsímil por el Seminario de Estudios Políticos de la Falange en Almería”, según relata Vanessa Tessada. ${ }^{8}$ Discípulo de Carl Schmitt en Berlín, fue de ideología falangista -de antigua adhesión socialista- el escritor político que ocupó la embajada en Montevideo entre 1959 y 1964, Francisco Javier Conde García, procurador en Cortes por la organización sindical que representaba al Instituto de Estudios Políticos, al que perteneció.59 Aún más puede decirse de Manuel Valdés Larrañaga, amigo de José Antonio, embajador de España en la República Dominicana entre 1951 y 1954, adonde retornó en 1959, e ínterin en Venezuela.60

\footnotetext{
${ }^{56}$ PARDO SANZ, Rosa María, "José María Doussinague, un director general de política exterior para tiempos duros", en Antonio César MORENO CANTANO (coord.), Cruzados de Franco, cit..

57 CARRIÓ, Macarena - FERMANDOIS, Joaquín, "Europa Occidental y el desarrollo chileno, 19451973", Historia, Vol. 36, Santiago, 2003, p. 25.

${ }^{8}$ TESSADA S., Vanessa, "Fronteras de la Comunidad Hispánica de Naciones. El aporte de la Sección Femenina de Falange y su proyección en Latinoamérica”, ILCEA [En ligne], 18 | 2013, mis en ligne le 11 juillet 2013, consulté le 29 avril 2016. URL: http://ilcea.revues.org/2068

59 Ver BLASCO GIL, Yolanda - CORREA BALLESTER, Jorge, "Franciso Javier Conde García, una cátedra de Derecho Político en una España sin constitución”, Presente y Futuro de la Constitución Española de 1978, Valencia, Tirant lo Blanch, 2005; SAZ, Ismael, "Franco, ¿́caudillo fascista? Sobre las sucesivas y contradictorias concepciones falangistas del caudillaje franquista", Historia y Política, núm. 27, enero-junio 2012; CUEVAS LANCHARES, Juan Carlos, Los intelectuales y la política en España. Francisco Javier Conde (1908-1974). La legitimación de la dictadura, Tesis doctoral. Universidad Complutense de Madrid, Facultad de Ciencias Políticas y Sociología, 2016.

60 Valdés se vinculó a Perón cuando éste, exiliado, recaló en Ciudad Trujillo, tras su estancia en Caracas, y previo al desplazamiento a la España de Franco, ver: GARCÍA, Marcela A. y ITURRIETA, Aníbal, "Perón en el exilio español", Todo es Historia, Buenos Aires, $\mathrm{N}^{\circ}$ 3134, agosto de 1993; CSIPKA, Juan Pablo, Los 49 días de Cámpora. Crónica de una primavera rota, Buenos Aires, Sudamericana, 2013.
} 
Entre todos ellos, resaltan las dos figuras relevantes de la literatura franquista que eran José María Alfaro y Polanco y Ernesto Giménez Caballero, falangistas históricos que llegaron a la región cuando ésta ya no estaba entre las opciones exteriores más atractivas del régimen. No obstante, la convulsa Argentina y el autoritario Paraguay adonde arribaron, retenían una atracción cierta de cara a expandir la economía española.

\section{En Asunción, Giménez Caballero}

Extravagante y contradictorio intelectual, ${ }^{61}$ doctorado en Filosofía y Letras por la Universidad de Madrid, y profesor de español en la de Estrasburgo, fue en La Gaceta Literaria que Ernesto Giménez Caballero había fundado en 1927, donde colaboraron estrechamente con José María Alfaro. ${ }^{62} \mathrm{Su}$ conocida obra Genio de España. Exaltaciones a una resurrección nacional y del mundo (1932) -seguida a poco por La nueva catolicidad-, le concedió fama entre una generación de intelectuales. Para entonces ya había descubierto al fascismo y pronto conoció a José Antonio Primo de Rivera, participando de la Falange. Tras la formación de la Junta de Defensa Nacional de Burgos y la designación del general Franco como jefe del gobierno del Estado, Giménez Caballero se incorporó a la Sección de Prensa y Propaganda. 63 Con la creación de las Cortes Españolas en 1942, GeCé (acrónimo literario de Giménez Caballero) será procurador, junto con personalidades de la cultura franquista como el mismo Alfaro, Fernando María Castiella, Jesús Suevos o Antonio Tovar. Fue dos veces Premio Nacional de Literatura y de Periodismo Francisco Franco, publicando una serie de ensayos a los que denominó Amor a ... dedicando sendos tomos a México y Argentina en los cuarenta, y años después a Paraguay y Bolivia. 64

\footnotetext{
${ }^{61}$ Ver ÁLVAREZ CHILLIDA, Gonzalo, "Ernesto Giménez Caballero: unidad nacional y política de masas en un intelectual fascista", Historia y política, julio-diciembre 2010; MINARDI, Adriana, "Devociones de lo nacional en la obra de Ernesto Giménez Caballero: Ensayo, genericidad e imagen", Anuario brasileño de estudios hispánicos, N. ${ }^{0}$ 26, 2016. También: SELVA ROCA DE TOGORES, Enrique, Ernesto Giménez Caballero. Entre la vanguardia y el fascismo, Valencia, Pre-Textos, 2000.

62 Giménez Caballero protagonizaría sonadas polémicas con revistas argentinas como Nosotros, donde se lo criticó por su falta de conocimiento del espíritu nacional, en ROSETTI, Mariana, "La polémica del Meridiano Intelectual de 1927. La lucha por el cauce de las corrientes intelectuales", Lexis, Vol. XXXVI (1), 2012.

${ }^{6}$ SELVA ROCA DE TOGORES, Enrique, "La insólita aventura de Ernesto Giménez Caballero", Revista Universitaria de Historia Militar, Volumen 7, número 13, 2018, p. 211.

64 MAINER, José Carlos, prólogo, "Ernesto Giménez Caballero o la inoportunidad", en Ernesto GIMÉNEZ CABALLERO, Casticismo, nacionalismo y vanguardia (Antología, 1927-1935), Madrid, Fundación Santander Central-Hispano, 2005, p. LXVI.
} 
Aunque a principios de 1954, Franco había recibido en El Pardo, a través del representante paraguayo en Madrid, la Gran Cruz de la orden Nacional del Mérito bordada en oro, para testimoniar la simpatía que se le profesaba a España y al caudillo, ${ }^{65}$ puede que Paraguay haya sido uno de los países latinoamericanos con los que el régimen menos contacto tenía. Por intervención del ministro de Educación Nacional Joaquín Ruiz-Giménez, ${ }^{66}$ Giménez Caballero fue designado agregado cultural en Asunción. En tiempos que España estaba teniendo éxito en su acercamiento con los Estados Unidos, aquel nombramiento se interpretó como una táctica para alejar al intelectual falangista, el que arrastraba el inconveniente mote de nazi-fascista que “comprometía demasiado".67 Viajó a destino en 1955, dictando conferencias, propiciando cursos de literatura y organizando conmemoraciones de los aniversarios franquistas con misas y actos -en febrero de 1956 participa de la Misión española que asistió a la toma de posesión del presidente Juscelino Kubitschek. Según refirió Giménez Caballero, el embajador en Asunción, celoso por su protagonismo en los ámbitos culturales y sociales, pidió su traslado a Brasil.68 Pero esas mismas fuerzas paraguayas y su presidente general Alfredo Stroessner, reclamaron su regreso y volvió a Paraguay en 1958, ya como embajador, donde permaneció por más de una década, con permanentes viajes a España -en repetidas ocasiones alabó la técnica de los aviones que permitían esos frecuentes desplazamientos. Al decir de Mainer, Giménez Caballero se entusiasmó con su misión diplomática, mientras se hacía amigo de Stroessner.69

Casi nonagenario recordaba GeCé que su sintonía con el régimen stronista y su aceptación en el medio se había debido a sus "proyectos para el país, casi en agonía, de desarrollo".70 Conocedor de la historia y la geografía paraguaya, Giménez Caballero supo advertir a sus superiores sobre la riqueza hídrica del país, dotado del "potencial

\footnotetext{
${ }^{65} \mathrm{Al}$ hacer entrega de la distinción, el gobierno de Paraguay señalaba que Franco venía "ganando para España lauros inmarcesibles, demostrando al mundo cómo se puede alcanzar trascendentales victorias en lo político, en lo militar, en lo económico, en lo social y en lo moral, sin mancillar la dignidad ni la soberanía de la nación, inspirándose en el respeto y amor a Dios y en los sabios principios de la religión católica", en $A B C$, Madrid, 8 de enero de 1954.

66 "Homenaje de despedida a don Ernesto Giménez-Caballero", $A B C$, Madrid, 27 de marzo de 1955.

${ }^{67}$ HARO TEGLEN, Eduardo, "Lo que no fue Giménez Caballero", El País, Madrid, 16 de mayo de 1988.

${ }^{68}$ Catálogo Cultural de la Mediateca del Centro Cultural de España. Ernesto Giménez Caballero. A fondo. Entrevista por Joaquín Soler Serrano. Programa completo, 1977, en https://www.youtube.com/results?search query=ernesto+gimenez+caballero++entrevista $++\mathrm{a}+$ fondo [Consultado: 20/07/2018]

69 MAINER, José Carlos, prólogo, “Ernesto Giménez Caballero...”, p. XIV.

70 GIMÉNEZ CABALLERO, Ernesto, “Crónica del Paraguay”, El País, Madrid, 30 de junio de 1987.
} 
energético mayor del continente”. Efectivamente, durante su gestión se concretaron convenios de asistencia técnica y financiera, se mejoró la conexión aérea que brindaba Iberia y lo más importante, el gobierno de Franco le vendió al Paraguay barcos de fabricación española, como también se hizo con la Argentina en el mismo tiempo. Favorecidos los contactos con el Banco Exterior de España, que financió la compra de unidades -unas 18-, los contratos comenzaron en $19588^{71}$ y se extendieron hasta principios de los años 1970. España construyó para el Paraguay tres buques motor cargueros, 4 barcazas de carga seca, una barcaza refrigerada que fueron entregados en 1960, un buque tanque, un buque frigorífico y una balsa transportadora de vehículos en 1961, dos buques cargueros provistos en 1966 destinados a la navegación del litoral norte del río Paraguay y dos buques motor para pasajeros más las motonaves “Presidente Carlos Antonio López” y “Presidente Stroessner”, entregados en 1967, con capacidad para más de trescientos pasajeros. En 1968 arribó el buque escuela fluvialultramar "Guaraní”, empleado por la Flota Mercante del Estado para cubrir la ruta Asunción hacia Europa y a la vez para entrenar al personal de la Armada paraguaya. ${ }^{2}$ Aquellos buques fueron construidos en los Astilleros Tomás Ruiz de Velasco, S.A., de Bilbao, siendo, en la verborragia de Giménez Caballero, una suerte de homenaje a la industria naviera vasca y al conquistador del país Domingo Martínez de Irala, vasco originario de la villa guipuzcoana de Vergara, considerado el fundador de los primeros astilleros paraguayos. En 1964 se negoció la instalación de un puerto y zona franca en Villeta, sobre el río Paraguay a 50 kilómetros al sur de Asunción, para depositar una amplia gama de productos españoles que podían ser interesantes a todo el mercado sudamericano. 73

El Poder ejecutivo paraguayo favoreció la acción exterior franquista en el país, al ceder a título de donación al Estado español, por ley 523 del 16 de julio de 1958, una fracción de terreno de propiedad fiscal para asiento de un edificio destinado a la sede

\footnotetext{
${ }^{71}$ Escribía el $A B C$, Madrid, 23 de agosto de 1958: "La firma de los convenios para la construcción por España de una flota fluvial paraguaya ha sido presentada por la Prensa como un acontecimiento que asegura la independencia económica de Paraguay, realizado merced al progreso industrial de la España actual y a la actuación de su embajador, señor Giménez Caballero".

72 ASAMAR (Asociación de Agentes Marítimos del Paraguay), Historia de la Flora Mercante del Estado, en http://www.asamar.org.py [consultado: 1-5-2018]

${ }_{73}$ La Vanguardia, Barcelona, 15 de agosto de 1963. Presidiendo la delegación que concurrió a la toma de posesión del nuevo mandato de Stroessner, el entonces ministro de Industria, Gregorio López Bravo asistió a la inauguración de las obras en Villeta, puerto destinado a favorecer el tráfico comercial entre España y Paraguay.
} 
de la cancillería de la embajada, del Banco Exterior de España y del Instituto de Cultura Hispánica, con el objetivo de fortalecer las relaciones bilaterales. En abril del año siguiente, Giménez Caballero fue nombrado "ciudadano de honor" del Paraguay, siendo condecorado con la Gran cruz de la Orden Nacional del Mérito, agasajado por la Asociación de Autores Paraguayos y la Academia Paraguaya de la Lengua Española.

A la par que la representación española avanzó con múltiples tratados, como el de doble nacionalidad, las sintonías estuvieron aceitadas por la coincidencia ideológica entre ambas dictaduras. Cuando el 4 de enero de 1960 el oficial de Estado Mayor español, coronel Manuel Escribano, visitó Asunción, el embajador concertó una audiencia con el mandatario paraguayo, que se desarrolló en términos de admiración al caudillo y a sus ejércitos liberadores, advirtiéndose que Stroessner

“...conocía perfectamente la vida militar del comandante Franco en La Legión ... y no digamos de la Cruzada encontrando y sacando muchas consecuencias paralelas en sus esfuerzos por la emergencia de España con los que él viene realizando por este noble pueblo en un gobierno verdaderamente patriarcal 'motejado, no obstante, como odiosa dictadura' por las democracias populares internacionales".74

Los gestos de cordialidad entre ambos países se repetían de forma constante, como cuando en julio 1961, Stroessner regaló un puma o león americano a España -y otro que se proveyó a cuenta de Giménez Caballero, quien los entregó personalmente a la casa de fieras del Retiro-75 o al año siguiente, en ocasión de agasajar en Asunción a los jugadores del Barcelona Futbol Club, que fueron recibidos en audiencia por el presidente paraguayo, que "les dirigió cordialísimas palabras, llenas de entusiasmo hacia España y hacia Franco", para declarar festivo el día del encuentro con la selección paraguaya. ${ }^{76}$

Si Giménez Caballero afirmaba que el Paraguay era "uno de los países más ordenados y prósperos de Hispanoamérica”, Stroessner se mantuvo consecuente. Necesitaba serlo porque el Paraguay no tenía entonces demasiados amigos internacionales: más allá de la cercanía con Washington, los gobiernos europeos le dispensaban indiferencia política y económica. Cuando en abril de 1964 un

\footnotetext{
74 Archivo del Ministerio de Asuntos Exteriores de España, Madrid (AMAEE), R. 5959/15, Buenos Aires, 9 de enero de 1960. Reservado, al Sr. Antonio Barroso Sánchez Guerra, ministro del Ejército, Madrid.

$75 A B C$, Madrid, 4 de julio de 1961.

${ }^{76}$ La Vanguardia, Barcelona, 6 de julio de 1962.
} 
pronunciamiento cívico-militar reemplazó al presidente João Goulart por el general Castelo Branco, Paraguay encontró en Brasil un importante aliado regional con el que compartir la lucha contra el comunismo y sus conexiones latinoamericanas. Ya jubilado Giménez Caballero, Stroessner recibió en el Palacio de López al ahora ministro de Asuntos Exteriores, Gregorio López Bravo, y volvió a expresar "su admiración y cariño hacia el General Franco, alabando el progreso realizado en España bajo su mando y su victoria sobre el comunismo".77

De visita en Madrid en julio de 1973, la presencia de Stroessner, acompañado de su esposa, generó una amplia campaña de propaganda y agasajos del cristalizado régimen de Franco. El ex embajador en Asunción estuvo entre los disertantes que alabaron su presencia en distintos actos y reuniones. ${ }^{78}$ En palabras de Matilde Eiroa, no faltaron las comparaciones entre ambos gobernantes y

“...su obra político-social y su misión como dirigentes destinados a salvar a sus patrias [...] Stroessner no se conformó con la obligada visita al Valle de los Caídos y El Escorial, sino que rindió homenaje ante la tumba de José Antonio en un estilo fascista poco acorde con el mundo que le contemplaba”.79

Según Giménez Caballero la experiencia paraguaya fue decisiva en su vida, pues era "la tierra donde se diera el comunismo integral desde los tiempos de los guaraníes", renovado "a la católica" por la orden de "Ignacio de Loyola con sus misiones ante el peligro de otro socialismo pagano reanudado por Tomás Moro con su Utopía”.80 Le dedicará a su experiencia de inmersión en la realidad cultural paraguaya varias obras: Revelación del Paraguay (1958) y luego Asunción, capital de América (1971). Escribirá frecuentemente en periódicos locales cómo La Tribuna. Allí, por ejemplo, expone en abril de 1960 la idea de "Asunción, capital religiosa de América”, señalando los esfuerzos que se estaban realizando: desde la creación de una universidad católica, las representaciones teatrales en el atrio de la Catedral de figuras históricas españolas,

\footnotetext{
77 AMAEE, R. 25.713/3. Viajes ministro López Bravo. Secreto. Paraguay (29 y 30 de marzo de 1971). ${ }^{78} \mathrm{ABC}$, Madrid, 18 de julio de 1973. En el acto académico que tuvo lugar en el ICH para homenajear a Stroessner, con la presencia de ministros españoles y paraguayos, "Giménez Caballero, ex embajador en Asunción, glosó la figura del ilustre huésped”.

79 EIROA SAN FRANCISCO, Matilde, "Acción exterior y propaganda. Las visitas de líderes latinoamericanos a Franco", Latino@mérica 54, 2012/1, p. 131-132. Ver también: EIROA SAN FRANCISCO, Matilde, Política internacional y comunicación en España (1939-1975). Las cumbres de Franco con Jefes de Estado, Madrid, Ministerio de Asuntos Exteriores, 2009, capítulo 3. 80 GIMÉNEZ CABALlERO, Ernesto, “Crónica del Paraguay”, El País, Madrid, 30 de junio de 1987.
} 
las procesiones del silencio. Incluía especialmente la difusión internacional de las misiones jesuíticas mediante un documental en color que filmó Giménez Caballero premiado en Italia y reconocido por los superiores jesuitas. Apasionado de la cinematografía, contó para el proyecto con la colaboración del noticiero español NoDo. Ello formaba parte de lo que era su "afán de contener la descatolización galopante de América hispánica. Y por tanto, su deshispanización”.81

Giménez Caballero se reconoció propulsor de las actividades del Opus Dei en Paraguay -se dirá amigo espiritual de su fundador, José María Escrivá de Balaguer-, 82 como así también de las labores de los franciscanos, de las monjas teresianas y de las Escuelas Laborales Salesianas. Por entonces, mencionaba la necesidad de una "nueva catolicidad" y veía al Opus como "el movimiento con el que la Iglesia, a través de Escrivá, había iniciado, una vez más, su nueva Contrarreforma".83 Años después supo calificar positivamente la oportunidad de la expansión de la institución secular, al comprenderse

“...que el Opus Dei era el órgano que ahora Roma necesitaba para afrontar no sólo el demonio de la técnica, sino su financiador el gran capitalismo, en manos, fundamentalmente de judíos y protestantes. Del mismo modo que también Roma incitaba a una Compañía como la de Jesús a renovar su tradición misionera y social, por lo que muchos sacerdotes jóvenes suyos comenzaron a evangelizar junto a comunistas. Claro que a los jesuitas hoy no les envidia nadie por exponer vidas y famas en sus abnegaciones sociales, lo que no sucede con los encargados de atraer un Nixon a España, sus dólares y negocios. Sin darse cuenta sus criticantes de que algunos ministros responsables de 'desarrollar una sociedad de consumo' entre nosotros, viven como ascetas y con menos necesidades que un 'hippy', y sabiendo cristianamente que su poder

\footnotetext{
${ }^{81}$ GIMÉNEZ CABALLERO, Ernesto, Retratos españoles (Bastante parecidos), Barcelona, Planeta, 1985 , p. 196.

82 Recuerda Giménez Caballero que cuando en noviembre de 1936 le insinúo a Franco, estando en Salamanca, la conveniencia de intentar una "Institución Libre de Enseñanza", pero a la católica, éste le respondió que "ya andaba por ahí un curita con esa idea, búsquele”. Se refería a José María Escrivá de Balaguer, el fundador del Opus Dei, con el que luego coincidió en algunas ocasiones en el Madrid de posguerra. "Siendo yo embajador y tras escribirnos desde el 8 de febrero del 62 para ayudarle a difundir su Obra por Paraguay", Giménez Caballero lo visitó en Roma el 2 de junio de 1963, ocasión en la que conversaron sobre las actividades del padre vallisoletano Ramón Taboada que había llegado a Asunción un año antes y su "tarea residencial de jóvenes y sus pláticas de adultos a las que acudían más bien elementos comerciales y catalanes como si olfatearan 'un negosi”, en GIMÉNEZ CABALLERO, Retratos españoles, cit., p. 196. Fallecido Taboada en Asunción en 2007, informaba el diario Ultima Hora del 18 de octubre, que el primer conciliario del Opus Dei en Paraguay fue "uno de los primeros profesores de la Universidad Católica donde enseñó Derecho Canónico, Teología y Filosofía en la Facultad de Derecho".

83 GIMÉNEZ CABALLERO, Retratos españoles, cit., p. 197.
} 
terminará en la expiación. Como un poco nos sucede a todos. Porque en España ni sentimos lo ruso ni sentimos lo otro; ya que nuestro genio es 'antieconómico', y vamos todos un tanto forzados a eso del consumo y la tecnocracia. Por ello nos salen, de pronto,

escándalos financieros y anarquías disparatadas”.84

Otro de los ámbitos a los que el embajador dedicó energía fue al Instituto Paraguayo de Cultura Hispánica, buscando favorecer el cultivo de la "paraguayidad", como proyección de la hispanidad. ${ }^{85}$ Respaldadas por la representación española, un grupo de personalidades de la cultura local habían fundado el 12 de octubre de 1949 aquel Instituto con el propósito de divulgar el libro español, constituir una biblioteca pública y favorecer el intercambio de profesores y alumnos. ${ }^{86}$ Una indagación más puntual podría listar dentro de sus miembros y participando de sus comisiones directivas a lo más significativo de la cultura paraguaya -que son mencionados por doquier en la prensa asunceña y española-, 87 a la par que no fue menor la importante labor editorial que llevó adelante el Instituto -igualmente disperso en referencias de bibliotecas y currículums.

Los historiadores proveyeron un enlace importante, así como un núcleo particularmente receptivo, de la sintonía con la cultura de la España de Franco. Cuando en octubre de 1960 la Academia Nacional de la Historia de la Argentina convocó en Buenos Aires el Tercer Congreso Internacional de Historia de América para conmemorar el Sesquicentenario de la Revolución de Mayo, la Real Academia Española de la Historia estuvo representada por una importante delegación -Manuel Ballesteros, Miguel Batllori, Jaime Delgado, Octavio Gil Munilla, Julio Guillén Tato, R. P. Francisco Mateos, Francisco Morales Padrón, Jesús Pabón, Ciriaco Pérez

\footnotetext{
84 Entrevista a Ernesto Giménez Caballero, en Eva JARDIEL PONCELA, Por qué no es usted del Opus Dei, Madrid, Editorial Gráficas Varela, 1974.

85 INSTITUTO PARAGUAYO DE CULTURA HISPÁNICA, Cuatro años de labor del Instituto Paraguayo de Cultura Hispánica (1958-1963), Madrid, Congreso de Instituciones Hispánicas, 1963.

${ }^{86} A B C$, Madrid, 18 de diciembre de 1949.

87 Ver, a modo de ejemplo, la visita de la delegación del ICH al Instituto Paraguayo, entonces presidido por el coleccionista e historiador Juan Bautista Gill Aguinaga. Encabezado por el secretario general Enrique Suárez de Puga, el grupo formaba parte de la Misión extraordinaria española que asistió a una nueva toma de posesión de Stroessner, $A B C$, Madrid, 20 de agosto de 1963. Tras la muerte de Franco, el Instituto Paraguayo de Cultura Hispánica -por entonces era su presidente el historiador Manuel Peña Villamil-, fue dando paso a una institución nueva, con el surgimiento en abril de 1976 -como derivación, evolución o variación-, del Centro Cultural de España Juan de Salazar, ver: Salazar 40, Asunción, AECID, 2016,
} 
Bustamante $^{88}$ y Dalmiro de la Válgoma. La mayor parte de los congresistas españoles se trasladó a Asunción para participar de distintos coloquios, regresando "encantados de las atenciones recibidas de nuestro embajador señor Giménez Caballero y de las autoridades paraguayas". ${ }^{89}$ Las visitas de historiadores paraguayos a la Madre Patria se repetían. En 1955 R. Antonio Ramos viajó a España con el apoyo del Ministerio de Educación y el ICH para investigar en los archivos de Indias, Simancas, Toledo y Vergara, seleccionando documentos sobre el gobernador Domingo Martínez de Irala cuyas copias "fueron entregadas luego por el gobierno español al gobierno del Paraguay". ${ }^{\circ 0}$ En noviembre de 1962, Julio César Chaves, presidente de la Academia Paraguaya de la Historia y también del Instituto Paraguayo de Cultura Hispánica, visitó Barcelona, en la que era su quinta estancia en el país donde había sido "recibido por el Caudillo Franco hace dos años". ${ }^{91}$ Señalan las crónicas periodísticas que la conferencia que impartió en el Instituto de Estudios Hispánicos llevó por título "Homérica guerra del Paraguay", según frase de Miguel de Unamuno. ${ }^{22}$ Con la asistencia de funcionarios y numeroso público, Chávez resaltó el heroísmo del pueblo paraguayo y la situación de ruina en la que quedó el país al finalizar el conflicto, para señalar que la lucha constituyó "una auténtica gloria de la hispanidad", parangonable con la resistencia de Numancia, Sagunto o Zaragoza. En el Club Universitario del Sindicato Español Universitario (S.E.U.) y para inaugurar el Aula Iberoamericana, pronunció otra conferencia sobre "Unamuno y América", tema de un libro que iba a editarle el ICH. En Madrid se entrevistó con su presidente, Gregorio Marañón Moya, para plantear el intercambio cultural entre los dos países.

Periódicamente algunos estudiantes paraguayos se verían beneficiados por becas de Cultura Hispánica o de los ministerios de Exteriores o Educación, bien que de manera menor que Argentina, Brasil o Chile. La concesión de condecoraciones fue otra metodología propagandista usual del régimen, que atraía funcionarios, militares y

\footnotetext{
${ }^{88}$ El historiador paraguayo Efraím Cardozo acompañó como relator al español Pérez Bustamante en una de las principales comisiones del Congreso cuyo tema general fue "La libertad y la independencia en el Nuevo Mundo".

89 La Vanguardia, Barcelona, 8 de noviembre de 1960. "La figura señera de España presidió permanentemente las sesiones del Congreso", subtitulaba la corresponsalía de Oriol de Monsant, seudónimo del agregado de prensa de la embajada de Alfaro, José Ignacio Ramos.

9o SCAVONE YEGROS, Ricardo, "Introducción. R. Antonio Ramos y los estudios históricos de las relaciones entre el Paraguay y el Brasil”, en R. ANTONIO RAMOS, La Independencia del Paraguay y el Imperio del Brasil, Brasilia, Fundación Alexandre de Gusmão, 2016, p. 34.

${ }^{91}$ La Vanguardia, Barcelona, 14 de noviembre de 1962.

${ }_{92}^{2}$ La Vanguardia, Barcelona, 17 de noviembre de 1962.
} 
periodistas, listado de favorecidos que también incluyó lo más granado de la sociedad paraguaya. 93

Apenas necesaria su actuación para atender, y menos controlar, al escaso colectivo de españoles radicado en territorio paraguayo, la protección del régimen franquista requirió de algunos cuidados propagandísticos, como en 1966 cuando tras lograr que el gobierno paraguayo prohibiera la exhibición de la película de Alain Resnais La guerra ha terminado, con libro del exiliado español Jorge Semprún, que propiciaba la embajada francesa, facilitó para su exhibición a uno de los principales cines de la capital el film Franco, ese hombre, al parecer con muy escaso éxito de público. 94

Giménez Caballero se dedicó también a observar las tensiones regionales que generó la proscripción y diáspora peronista, así como permanecerá atento a los movimientos de exiliados anti-stronistas que desde territorio argentino intentaron la invasión de Paraguay -a quien los gobiernos de Buenos Aires acusaban de asilar peronistas, y permitir actividades proselitistas-, en especial durante los gobiernos de Pedro Eugenio Aramburu y de Arturo Frondizi. Por entonces, más de medio millón de paraguayos, uno por cada seis habitantes, se habían refugiado en la Argentina, huyendo de la violencia política y de la dictadura.95 Los momentos más críticos se

93 Acompañada de un boato peculiar, las distinciones que otorgaba España conllevaban una gran difusión en la prensa y daban lugar a reuniones sociales y políticas. Para Paraguay, además de las que se han mencionado en este trabajo, ver: $A B C$, Madrid, 12 de febrero de 1967, que informa de la entrega en nombre de Franco de parte del ministro de Marina, almirante Pedro Nieto Antúnez, al general Stroessner de la Medalla de Oro de la Marina Española, a la par que Giménez Caballero impuso "varias condecoraciones hispanas a personalidades del gobierno paraguayo".

94 RUIZ NESTOSA, Jesús, "Contra el olvido", ABC Color, Asunción, 7 de marzo de 2014. Giménez Caballero se plegaba así a las instrucciones globales de su gobierno: "Resnais realiza en 1965 La guerre est finie, con guion de Jorge Semprún, obra no sólo prohibida en la España de Franco (se permite su estreno únicamente en 1977, pero con restricciones, subtitulada y en salas especiales), sino vetada a instancias del gobierno español en aquel festival de Cannes, donde tuvo que presentarse fuera de concurso", en Fernando González, "Exilio, identidad, historia, forma fílmica. La guerre est finie, Nueve cartas a Berta", Filmhistoria, Vol X, No. 1-2, 2000, p. 30.

95 A fines de 1959, el plenario de las 62 organizaciones obreras argentinas envió a la Confederación Paraguaya de Trabajadores un mensaje en representación de cuatro millones de obreros argentinos, "de repudio a la actitud de autoridades argentinas que permitieron que territorio nacional sirviera de cabeza de puente para la invasión de rebeldes paraguayos. Declaramos que auténtico pueblo argentino tienen deuda de gratitud con Stroessner”. La asamblea terminó aclamando el nombre de Paraguay y del presidente Stroessner, guardando un minuto de silencio en homenaje a los paraguayos caídos en defensa de las instituciones, en AMAEE, R. 5959/15. Asunción, 23 de diciembre de 1959, de Ernesto Giménez Caballero a ministro, y Buenos Aires, 21 de diciembre de 1959, de embajador José María Alfaro a ministro. 
registraron a fines de marzo de $1958^{96}$ y diciembre de 1959,97 cuando fuerzas irregulares entrenadas y pertrechadas en Argentina y Uruguay intentaron operaciones de guerrilla contra territorios limítrofes del Paraguay. Informes diplomáticos consultados, ${ }^{98}$ muestran la permanente comunicación, atención al tema y combinación de acciones no sólo con Madrid, sino con la embajada de Alfaro en la Argentina. Tras la crisis desatada en diciembre de 1964 por el intento de retorno de Perón, la perspectiva de su llegada a territorio paraguayo y su detención en Río de Janeiro -para ser devuelto a su exilio español-,99 Giménez Caballero deberá desmentir las periódicas noticias periodísticas que señalaban que el ex presidente amenazaba con instalarse en Paraguay contando con el asentimiento de Stroessner, para desde allí intentar la entrada a la Argentina. El embajador español más se las atribuía a los propios medios propagandistas del peronismo, que Asunción dejaba correr para presionar a Buenos Aires frente al problema de la navegación del río Paraguay. Los vínculos que mantenía

${ }_{96}^{6}$ FIGALLO, Beatriz, "La Argentina, el Cono Sur y las migraciones políticas tras el derrocamiento de Perón”, Revista Enfoque Social, núm. 2, 2007.

97 FERRERO BLANCO, María Dolores-EIROA SAN FRANCISCO, Matilde, "1959: los intentos de derrocamiento de las dictaduras de Trujillo, Stroessner y Luis Somoza”, Historia Actual On Line, 39 (1), 2016.

98 España lograba así triangular la información entre Asunción-Buenos Aires-Madrid. Ver, a modo de ejemplo, AMAEE, R. 5044/3. Política exterior argentina, Buenos Aires, 14 de abril de 1958, donde Alfaro analiza el accionar de los exiliados paraguayos en Buenos Aires, la connivencia entre el embajador de la República Dominicana en Asunción, Cirilo José Castellanos con el enviado de Perón allí, John William Cooke. En R. 5542/30, Viaje a Asunción de Frondizi, 58-9, Asunción 5 de septiembre y 24 de octubre de 1958, Giménez Caballero informa sobre la situación política argentina y las relaciones argentinoparaguayas. El 31 de octubre se reporta en extenso la visita de Frondizi, y analiza sus objetivos geopolíticos, "significa un intento argentino de contender con la nación brasileña". Luego reseñará la denuncia de un intento de organizar un atentado contra el presidente argentino esos días, en R. 5034/5. Agitación Política. Caso Satanowsky - Atentado presidente Frondizi vistos desde Paraguay, Asunción, 8 de noviembre de 1958. En ese sentido, resultaba importante la información que podía brindar Giménez Caballero referida a las provincias argentinas vecinas al Paraguay -Formosa, Misiones, Corrientes, Chaco-, pues advertía sobre la internación de residentes y exiliados paraguayos en la frontera, que eran trasladados a Buenos Aires a fin de preservar la seguridad en la frontera, en R. 5448/34. Actual amistad de Argentina y Paraguay, 17 de abril de 1959. En diciembre Giménez Caballero informará puntualmente sobre "el golpe de estado fracasado en Paraguay", producto del "intento de invasión fronteriza desde Argentina", señalando que si los gobiernos de Buenos Aires seguían permitiendo la actividad de aquellos "guerrilleros", "sería el caso de traer a esta frontera a Juan Perón, para las próximas elecciones de marzo", en R. 5959/15, Asunción, 13 de diciembre de 1959. Las informaciones se repetirán ante nuevos ataques fronterizos en 1960, a los que Giménez Caballero le atribuía gran peligrosidad y filiación comunista, adjudicándole a alguno de sus líderes, la posibilidad de "transformarse en el Fidel Castro paraguayo", en R. 5959/15, Asunción, 14 de julio de 1960. A la par, el embajador español se congratulaba de la diplomacia paraguaya que para neutralizar cualquier ayuda proveniente de la Argentina a los exiliados y rebeldes, había "sabido jugar ante Buenos Aires la carta brasileña y el peligro castrista en el Plata”, en R. 5972/18, Asunción, 30 de septiembre de 1960.

99 AMAEE, R. 7520/3, Asunto: Perón y Paraguay, Asunción, 4 de diciembre de 1964, Ernesto Giménez Caballero. Escribía: “mientras los gobiernos de Argentina, Brasil y Uruguay se pusieron muy nerviosos y emitieron declaraciones a través de ministros y voceros, Paraguay permaneció perfectamente tranquilo y silencioso". 
en la Argentina -como con el “catalán y gran patriota español” José Figuerola, a quién había conocido en 1927, en tiempos de su fundación de La Gaceta Literaria, cuando éste era secretario de la Cámara del Libro de Barcelona y colaborador de Aunós, ministro de Primo de Rivera, y a quién le atribuía la invención del término “justicialista”- le señalaban que por entonces no había mucha esperanza para la vuelta de Perón. ${ }^{100}$

No será esta la única proximidad con el peronismo. Revela la investigación de Yazbek y Queipo Riavitz que Giménez Caballero contribuyó en las publicaciones del Sindicato Unidos Petroleros del Estado, entre las décadas del sesenta y setenta, a través de las columnas de opinión de Petróleo Argentino. Sus exhortaciones a los trabajadores son de corte conciliador y corporativo pero a la vez, movilizador, ofreciendo, con su habitual exaltación literaria, un modelo sindical que recordaba al propuesto por el falangismo; "al tiempo que deplora el marxismo, Giménez Caballero exalta la tradición anarquista, que desembocaría en el anarcosindicalismo". ${ }^{101}$

Retirado por el ministro de Asuntos Exteriores opusdeísta López Bravo que había asumido la cartera en octubre de 1969, ${ }^{102}$ en agosto de 1970, Giménez Caballero "repatriado de ultramar después de largos años de embajador en el Paraguay, ha vuelto a su casa". Propugna que se cambie el nombre de la plaza de Colón de Madrid, en trance de ampliaciones, por el de la Hispanidad: "Ernesto regresó del Paraguay sudando hispanidad”. ${ }^{103}$ Su amistad con los peronistas -entre ellos Pavón Pereyra- siguió dando frutos. Si en las vísperas del definitivo retorno de Perón a la Argentina publica en el diario El Alcázar tanto la correspondencia entre ambos como un laudatorio artículo sobre el expresidente argentino ${ }^{104}$ y concurre a despedirlo al aeropuerto de Barajas, fallecido el líder justicialista, reclamará que “el cadáver de Perón se haga Vida. Tumba

\footnotetext{
100 AMAEE, R. 8320/27. Asunto: Perón y Paraguay. Asunción, 25 de enero de 1966. Ernesto Giménez Caballero.

${ }^{101}$ YAZBEK, Susana y QUEIPO RIAVITZ, Anandí, “La España franquista como modelo de organización social para el sindicalismo argentino. El caso de la Federación Sindicatos Unidos Petroleros del Estado (SUPE)", en XIV Jornadas Interescuelas/Departamentos de Historia, Mendoza, 2013, p. 18.

102 GIMÉNEZ CABALLERO, Retratos españoles, cit., p. 196.

103 ERO, "Genio de Madrid", La Vanguardia, Barcelona, 11 de agosto de 1970. El 22 de mayo de 1970 pronunció en el Salón de las Banderas del Ministerio de Defensa del Paraguay una arenga proclamando a Asunción capital de la América Hispana. Presente en el acto, Efraím Cardozo señalaba que se trataba de un "ideal que vemos paradójicamente reproducido por el mariscal López, en plena guerra, en su entrevista con el general Mitre, en Yataity Corá”, en GIMÉNEZ CABALLERO, Ernesto, Asunción, capital de América, Madrid, Ediciones cultura Hispánica, 1971, p. 218.

104 El Día, La Plata, 7 de junio de 1973.
} 
nacional ... un Valle argentino de sus caídos". ${ }^{105}$ Asegura que fueron amigos -lo cual parece ser incierto- desde los tiempos que coincidieron en Roma, cuando Perón era ayudante del agregado militar de la embajada argentina entre abril de 1939 y 1940 quien tras la entrada de Italia en la II Guerra Mundial regresó a Buenos Aires el 27 de mayo de 1941-, y Giménez Caballero, casado con una italiana, frecuentaba la ciudad; que fue amigo también de Eva, y en el exilio de María Estela Martínez de Perón.

\section{En Buenos Aires, Alfaro}

Designado en 1947 representante diplomático en Colombia, desde octubre de 1955 Alfaro fue embajador de Franco en la Argentina. ${ }^{106}$ Abogado de formación, su trayectoria cultural incluía su identificación como el poeta oficial del falangismo, ${ }^{107}$ así como se recordaba el cargo de subsecretario de Prensa y Propaganda que desempeñó bajo las órdenes del ministro de la Gobernación Ramón Serrano Suñer.108

Sus primeros cometidos estuvieron destinados a cortar críticas contra el régimen franquista que recrudecieron en la Argentina después del golpe de septiembre de ese año que derrocó a Perón, valiéndose de su experiencia como periodista y de los colaboradores de los que disponía en la embajada, desde el agregado José Ignacio Ramos, ${ }^{109}$ uno de los primeros miembros de la Falange Española en la Argentina, ${ }^{110}$ hasta el consejero cultural José Pérez del Arco, culto abogado de vinculaciones con la prensa argentina y con la señera Institución Cultural Española creada en 1912. En 1957 se sumaría el

105 GIMÉNEZ CABALLERO, Ernesto, “iYo te invoco Argentina!", Patria peronista. Órgano de Reafirmación doctrinaria, Año 2, Nro. 17, $1^{\text {a }}$ Quincena de agosto de 1974.

${ }^{106}$ FIGALLO, Beatriz, "Diplomacia franquista, propaganda y control de los exiliados. La embajada de José María Alfaro en la Argentina, 1955-1971", Épocas, 11, 2015; CERRANO, Carolina, "Diplomacia franquista ante la política argentina, 1955-1962", en Beatriz FIGALLO, Desarrollismo, franquismo y neohispanidad, cit..

107 En RODRÍGUEZ PUÉRTOLAS, Julio, Historia de la literatura fascista española. I, Madrid, Akal, 2008, p. 139. Alfaro colaboró en la letra del himno de la Falange, el Cara al sol, que escribirá conjuntamente con José Antonio Primo de Rivera, Agustín de Foxá y Dionisio Ridruejo.

${ }^{108}$ ARGAYA ROCA, Miguel, Historia de los falangistas en el franquismo. 19 de abril 1934-1 abril 1977, Madrid, Plataforma, 2003, p. 132.

109 Nacido en 1904 en Santiago de Compostela, era abogado y licenciado en Filosofía y Letras. Fue corresponsal de La Vanguardia, de Barcelona, colaborador del porteño La Nación y delegado de la Sociedad General de Autores de España. En RAMOS, José Ignacio, Biografía de mi entorno. Nostalgias, recuerdos, testimonios, Buenos Aires, Legasa, 1984, le dedica un capítulo, y señala en p. 204: "qué generosidad para invitar a su mesa casi a diario a intelectuales, periodistas, políticos, militares".

${ }^{110}$ Ver MORENTE, Francisco, "Rafael Sánchez Mazas y la esencia católica del fascismo español”, en Miguel Á. RUIZ-CARNICER, editor, Falange. Las culturas políticas del fascismo en la España de Franco (1936-1975), Zaragoza, Institución Fernando el Católico, 2013, p. 120. 
cónsul general en Buenos Aires Miguel María de Lojendio, también de antigua filiación falangista. ${ }^{111}$ Pero el gran apoyo propagandístico que recibió Alfaro le vino de los corresponsales españoles de prensa destacados en la Argentina, que con distinto grado de adscripciones o simpatías por el régimen estaban concentrados en los vínculos culturales, más que en afinidades ideológicas, ${ }^{112}$ y que compartían con literatos y escritores españoles, franquistas o republicanos exiliados, la publicación en muchos suplementos literarios de periódicos o la participación en conferencias y transmisiones radiotelevisivas.

Siendo necesidad perentoria de España revitalizar sus relaciones económicas, supo Alfaro esquivar las críticas contra la dictadura española de demócratas y liberales, de partidos políticos y agrupaciones universitarias, para acceder a otros grupos de poder en la Argentina posperonista. Se conectó con Teodoro Hartung, ministro de Marina del gobierno de la Revolución Libertadora, sector desde donde había salido el nombramiento del embajador en Madrid en diciembre de 1955, contraalmirante Samuel Toranzo Calderón, encargado de reanudar las negociaciones comerciales entre ambos países. ${ }^{113}$ Las vinculaciones del embajador se fueron extendiendo por estamentos militares y policiales -por ejemplo, la Sección Anticomunista de Coordinación Federal, del Ministerio del Interior-, útiles para ejercer control sobre las actividades de agrupaciones latinoamericanas pro amnistía de presos y exilados políticos de España y Portugal, ${ }^{114}$ y de emigrantes vascos, gallegos y catalanes críticos del régimen franquista, bajo la acusación de ser comunistas. ${ }^{115}$ La tarea de controlar los movimientos en la Argentina de los intelectuales españoles republicanos mostró diferentes caras: desde las quejas oficiales por la acogida social y la recepción que hiciera el vice presidente argentino almirante Isaac Francisco Rojas del escritor Arturo Barea, al

\footnotetext{
${ }^{111}$ Renunciante de la embajada de la República Española en Santiago, Miguel de Lojendio se convertirá en jefe de la Falange Española en Chile, ver: Fabián Almonacid Zapata, "Españoles en Chile: reacciones de la colectividad frente a la República", Revista Complutense de Historia de América, 2004, vol. 30. Volvió a Chile como embajador en 1966.

${ }_{112}$ FIGALLO, Beatriz, "La Revolución Libertadora y la Guerra Civil Española como mito de origen. Identificaciones y paradojas de dos dictaduras de liberación", en María Valeria GALVÁN y María Florencia OSUNA (comp.), La "Revolución Libertadora" en el marco de la Guerra Fría. La Argentina y el mundo durante los gobiernos de Lonardi y Aramburu, Rosario, Prohistoria, 2018. pp. 26-7.

${ }_{113}$ AMAEE, R. 4454/ 4, Situación interna después de la caída del régimen peronista. Buenos Aires, 1 de noviembre de 1955. De embajador José María Alfaro a Alberto Martín Artajo, ministro de Asuntos Exteriores.

${ }_{114}$ AMAEE, R. 6566/ 4, Buenos Aires, 7 de noviembre de 1960, de Alfaro a ministro.

${ }^{115}$ La Prensa, Buenos Aires, 9 de septiembre de 1961.
} 
que calificó de "persona ultraizquierdista, de formación completamente liberal y como clásico representante de la intelectualidad de izquierda acatólica", ${ }^{116}$ a estorbar la contratación de Luis Jiménez de Asúa como profesor de la Facultad de Derecho de la Universidad de Buenos Aires bajo la acusación de ser un refugiado que tenía actuación política efectiva, ${ }^{117}$ merced a sus contactos sociales con sectores conservadores y nacionalistas. ${ }^{118}$

Cuando Alfaro cumplía dos años al frente de su cargo, editorializaba el diario $A B C$ :

“...con paciencia y tacto ejemplar ha ido haciéndose oír en centros españoles. Su serenidad, sus buenos modales y un gran tacto lo han permitido. Centros españoles un tanto reacios, por errores propios y ajenos se han ido acercando para acabar convertidos en entusiastas colaboradores y asiduos visitantes a la embajada. Hacía poco le había impuesto la Cruz del Mérito Militar al general Solanas Pacheco, comandante del cuerpo de Caballería, ante más de cien altos jefes y oficiales del ejército". ${ }^{119}$

Interesados ambos gobiernos en resolver sus diferendos financieros, empresas españolas comenzaron a construir dos centrales hidroeléctricas en la cordillera de los Andes, así como se proponía un comercio que permitiría intercambiar buques y trenes por cereales, carnes, cueros y lanas. En ese contexto, Alfaro logró convencer al gobierno de Aramburu de evitar referencias injuriosas de la prensa contra el régimen franquista, a fin de colaborar para el mejor desenvolvimiento de la política exterior argentina. ${ }^{120}$

Controlado el envejecido exilio, acercadas y atendidas las dirigencias de los centros regionales y comunidades de emigrantes, vitalizada la cultura española en los medios de comunicación, Alfaro tanto se dedicó a fomentar la política de becas para argentinos y el intercambio universitario como actuó de nexo con la prensa argentina para mostrar la "nueva España". Sus contactos con el diario Clarín y sus directivos

\footnotetext{
${ }_{116}$ AMAEE, R. 4463/11, Buenos Aires, telegrama 27 de abril de 1956. Precedido por el éxito de La forja de un rebelde, editado en Buenos Aires en 1951, Barea fue enviado por la BBC en una gira por Argentina, Chile y Uruguay. En Buenos Aires asistió a numerosos banquetes, entrevistas y firmas de libros, siendo sus conferencias ampliamente difundidas en la prensa, destacando tanto las referencias que hizo en contra del régimen franquista, como también la mención de los asesinatos ocurridos en el bando republicano. Ver también: MONFERRER CATALÁN, Luis, Odisea en Albión: los republicanos españoles exiliados en Gran Bretaña 1936-1977, Madrid, Ediciones de la Torre, 2007, p. 432.

${ }_{117}$ AMAEE, R. 7251/35, Buenos Aires, 1 de julio de 1963, de Alfaro a ministro de Asuntos Exteriores.

${ }^{118}$ FIGALLO, Beatriz "De Jiménez de Asúa a Perón: sus exilios como componentes de la política exterior hispano-argentina”, Temas de historia argentina y americana, N. ${ }^{0}$ 15, 2009.

${ }^{119} A B C$, Madrid, 27 de noviembre de 1957.

${ }^{120}$ AMAEE, R. 4295/1, Buenos Aires, 27 de junio de 1957, de Alfaro a ministro.
} 
fueron muy estrechos, así como también con Primera Plana, a cuyo periodista Osiris Troiani facilitó en 1964 los contactos oficiales necesarios para realizar un reportaje en España que se titularía “Franco, 25 años después”, ilustrada la portada con una prolija imagen de civil del caudillo, ya que la influyente revista "le venía prestando muy buenos servicios a la embajada y al régimen", pues "informa constantemente sobre el resurgimiento español bajo la guía de su ilustre jefe”. ${ }^{121}$ Troiani recogía variadas razones que alcanzaban para explicar la perdurabilidad del franquismo. El ministro de Comercio Alberto Ullastres ubicaba al país a mitad de camino en su proceso de desarrollo económico, aunque afirmando que España no era "un país subdesarrollado, porque el despegue se ha producido ya", ${ }^{122}$ mientras el de Asuntos Exteriores recordaba que en febrero de 1962 se había solicitado la apertura de negociaciones con el objeto de examinar la posible vinculación con la Comunidad Económica Europea. Tras el despegue, "vendrá el salto" que sería el intercambio con Europa, capaz de multiplicar "en modo asombroso las posibilidades del mercado español, con obvios beneficios para Iberoamérica”. El reportaje de Primera Plana explicaba el excepcional uso de Franco de la camisa azul prescripta por José Antonio Primo de Rivera, como "parte de su botín de guerra" y de su determinación "para limitar sus veleidades revolucionarias", considerando que sus sucesivos jefes Raimundo Fernández-Cuesta, José Luis Arrese y José Solís habían contribuido a domesticarla, aunque los falangistas de a pie seguían considerándose la izquierda del régimen, proclamando el nacionalismo económico y la justicia social. La nota también mencionaba los nombres de los ministros del Opus Dei, señalando que agrupaba a "hombres devotos bajo una regla austera, casi monacal, y los instruye para actuar en la vida pública", que ya formaban un equipo en el régimen. Contaba con la oposición de la Falange que recelaba de su inclinación "europeísta" y que para obtener la incorporación al Mercado Común, se obligase a España a sacrificar su originalidad política. ${ }^{123}$

Además de difundir una realidad española de progreso en la Argentina, Alfaro se concentró en utilizar la cercanía con lo español de conservadores sectores cultos e ilustrados de la sociedad porteña. Habitual concurrente y disertante en la Academia Argentina de Letras y la Academia Nacional de la Historia, fruto de su esfuerzo, en 1965

\footnotetext{
${ }^{121}$ AMAEE, R. 7616/4, Buenos Aires, 9 de marzo de 1964, de Alfaro a Castiella.

122 TROIANI, Osiris, “España: “Qué vendrá después de Franco?”, Primera Plana, N $^{\circ} 77$, Buenos Aires, 28 de abril de 1964, p. 10.

${ }^{123}$ TROIANI, Osiris, “España”, cit., p. 12.
} 
se inauguraron los amplios y lujosos locales en que habría de funcionar en Buenos Aires el Instituto Argentino de Cultura Hispánica. Su consejo de honor reunía a importantes personalidades del país, desde el Nobel Bernardo Houssay hasta Jorge Luis Borges. Además de conferencias, se comenzaron a dictar allí cursos regulares de política internacional, sociología, perfeccionamiento docente, problemas económicos y sociales, historia de la cultura, filosofía y cuestiones de espiritualidad tratados en el Concilio Vaticano II. Un fiel público acompañaba aquellas presentaciones, incluso oficiales y jefes de las fuerzas armadas. El doctor Rómulo Garona Carbia, que presidiría aquella institución y era sobrino del historiador Rómulo D. Carbia, autor de Historia de la Leyenda Negra, además de manifestar su admiración por la pujanza de la España de Franco, afirmaba: "España goza hoy de la heroica decisión que tomó un día, que representaba la batalla contra los principios destructores del marxismo revolucionario". ${ }^{124}$ Lo cierto es que el instituto argentino y sus filiales en distintas provincias, además de intermediar en la concesión de las becas para estudiantes del interior del país, desarrollaron "la más sistemática y planificada empresa cultural hispánica". ${ }^{125}$ Durante aquellos años de la embajada de Alfaro, otros organismos compartieron el objetivo de colaborar en la "exaltación y estudio del genio y la cultura hispánicos": en Buenos Aires, la "Fundación Pedro de Mendoza", que funcionaba en la casa de Enrique Larreta, con cursillos dirigidos por el profesor Ángel Battistessa a través del Instituto del Idioma, director de la revista Cuadernos del Idioma, la Asociación Argentina de Mujeres Hispanistas, el Centro de Estudios Hispanoamericanos, la "Mesa Española” que reunía a conocidos hispanistas argentinos. En 1966 se instaló en Buenos Aires la Librería Española, para que el público lector pudiera encontrar la mayor parte de la producción editorial española. Se reprodujeron también cátedras de Historia de España, propiciadas por impulso de ex becarios en España, surgiendo en universidades públicas y confesionales como la Católica Argentina y la del Salvador.

Producido el golpe de junio de 1966, satisfecho porque de las instituciones hispánicas habían surgido funcionarios importantes, como los responsables de Exteriores y Educación, así como algunos embajadores, ${ }^{126}$ Alfaro frecuentará a los más altos jerarcas de la Revolución Argentina, entre ellos al general Pascual Pistarini,

\footnotetext{
124 La Vanguardia, Barcelona, 10 de junio de 1965.

125 CUEVILLAS, Fernando de, "Las organizaciones españolas de cultura”, en ÁLVAREZ, Gerardo (coord.), España en la Argentina. Buenos Aires, 1997, p. 94.

${ }^{126}$ AMAEE, R. 8362/2, Buenos Aires, 28 de julio de 1966, de Juan Castrillo a Pedro Salvador.
} 
integrante de la Junta Militar Revolucionaria, y Juan Iavicoli, jefe del Estado Mayor del Ejército. En el presidente general Juan Carlos Onganía, a su vez, verá que "el ejemplo de la España de hoy -que íntimamente admira- ha de pesar mucho en su pensamiento". ${ }^{127}$ Cultivó amistades políticas en distintos despachos ministeriales, en especial, con quienes habían sido becarios argentinos. Todo ello permitió que las actividades culturales vinculadas a la España oficial ocuparan un lugar de privilegio, en instituciones y organismos oficiales.

Para cuando en 1970, Alfaro abandonó la embajada, en una década el intercambio comercial entre Argentina y España se había duplicado. Era ello un logro, pues como consecuencia de los litigios por los pagos de créditos argentinos, las relaciones económicas eran casi nulas a su arribo. Recién en 1963 se llegó a un acuerdo, por el cual España pagaría a la Argentina con la construcción de barcos de sus propios astilleros. ${ }^{128}$ Pero eso fue sólo parte de un acercamiento que tuvo como objetivo el establecimiento de una relación privilegiada, que sin dejar de atender -de momento- al tradicional interés español por las carnes y los cereales, introdujera los suministros industriales y de ingeniería como contrapartida española. No fue sencillo y requirió más que el empeño del embajador, sino concurrentemente la presencia de funcionarios comerciales en Buenos Aires y en Madrid, giras de ministros y visitas de empresarios y banqueros, ya que España era una recién llegada al mercado argentino, debiendo abrirse camino en competencia con los grandes países industrializados, cuya presencia databa de décadas. El agregado comercial de la embajada, Eduardo Peña, era contundente: "Estamos intentado basar en Argentina nuestra política comercial global futura con Iberoamérica [...] auténtica cabeza de puente económico y comercial en este continente". ${ }^{129}$ En pocos años, Argentina y la región se habían convertido en una zona óptima para las exportaciones industriales españolas, con sus máquinas, material de transporte, barcos, así como para sus inversiones y sus bancos.

\section{Consideraciones finales}

Hacer la historia de los casi quince años en los que aquellos embajadores

\footnotetext{
127 AMAEE, R. 8316/11, Iberoamérica. Nota informativa. Madrid, 25 de agosto de 1966.

128 FIGALLO, Beatriz, "Estrategias políticas y económicas de la tecnocracia franquista en la Argentina, 1959-1973", Investigaciones y ensayos, N. ${ }^{\circ}$ 56, 2007.

129 AMAEE, R. 10172/4, Buenos Aires, 22 de octubre de 1968, de agregado comercial a director Álvaro Iranzo.
} 
representaron a la dictadura franquista en la Argentina y Paraguay, implica medir el pulso del régimen en el Cono Sur y constatar su evolución y su pragmatismo exterior, verificando el rumbo eficaz que alcanzaría en los años ' 60. Implica también comenzar a identificar los sectores sociales y políticos locales que fueron sensibles al influjo ideológico y a las propuestas de un ordenamiento a la vez autoritario y desarrollista que, por distintas vías -culturales, religiosas, militares, de emprendimientos industriales, técnicos, financieros-, la acción exterior de España les estaba haciendo llegar

Inconvenientes al régimen, pero fieles al mismo tiempo, ${ }^{130}$ Alfaro y Giménez Caballero recurrieron a todos los instrumentos de una cultura hispánica de valores conservadores que permitieran a la vez acompañar la introducción de los cambios que se estaban gestando en España. Cómodos para desempeñar sus funciones lidiando con las formas autoritarias que primaban en Paraguay y asediaban en la Argentina, definidas sus estrategias a través de sus vinculaciones con los estamentos militares y de poder, fueron eficaces medios para permitir que la tecnocracia desarrollista del franquismo desplegase una política exterior donde ya primaban intereses económicos no de supervivencia sino de expansión, planes de modernización e incluso expectativas de una controlada transición institucional. Su contribución a la dictadura española no fue menor, pues supieron captar adhesiones y voluntades, se empeñaron en persuadir sobre la viabilidad de las dictaduras del desarrollo, crearon climas propicios para negocios, intercambios e inversiones, favorecieron contactos de futuro, dejaron capacidades instaladas, en lo político e ideológico, y permitieron a los gobiernos de Madrid consolidar su presencia internacional en espacios sudamericanos, incluso en competencia con las grandes potencias de la Guerra Fría. Sin ser prevalentes como influencias intelectuales en las cambiantes sociedades platenses de los años ' 70 , tampoco son desdeñables la incidencia de sus discursos a favor de posibilidades institucionales adecuadas a los pueblos de raíz hispánica, no necesariamente democráticas. El artículo, con ser extenso, no concluye, sino que analiza y deja planteada una agenda de temas a investigar que pueden abordar con mayor profundidad múltiples aspectos que aquí se esbozan y mencionan y se manifiesta abierto a las derivas que puede generar.

Cuando se avecinaba un abierto final para el franquismo -atado a la desaparición

\footnotetext{
${ }^{130}$ Declaraba Alfaro en una entrevista a Juan Pedro Quiñonero, en Informaciones, Madrid, 17 de febrero de 1976: "He decidido no escribir mis memorias. Mi última lealtad al Régimen será esta".
} 
de Franco- Giménez Caballero no se privaría de comparar elogiosamente la figura del dictador Stroessner como hombre, como militar y como ciudadano, con la de Franco, poniendo al pueblo paraguayo como ejemplo de patriotismo y lealtad a España, mientras Alfaro era ya señalado como parte de un núcleo intelectual de vocación liberal, una suerte de "falangismo liberal", ${ }^{131}$ que fue distanciándose del régimen, para permitir instaurar en España un sistema político que aunque no fuese una república, fuera más aceptable para las democracias occidentales. En gran medida, eran reflejo de las tendencias que cada uno había imprimido a las conexiones de la España del desarrollo con Paraguay y Argentina.

\section{Bibliografía}

ABELLÁN, José Luis. "La muerte de Ortega y Gasset y la generación de 1956". Triunfo, Madrid, 23 de junio de 1979.

AGUILERA SASTRE, Juan. "Entre dos exilios. Rivas Cherif y García Lorca”. Archivum, Tomo 63, 2013.

ALMONACID ZAPATA, Fabián. "Españoles en Chile: reacciones de la colectividad frente a la República", Revista Complutense de Historia de América, 2004, vol. 30.

ÁLVAREZ CHILLIDA, Gonzalo. "Ernesto Giménez Caballero: unidad nacional y política de masas en un intelectual fascista”. Historia y política, julio-diciembre 2010.

AREILZA, José María de. Memorias exteriores. 1947-1964. Barcelona, Planeta, 1984.

ARENAL, Celestino del. Política exterior de España y relaciones con América Latina. Iberoamericanidad, europeización y atlantismo en la política exterior española. Madrid, Fundación Carolina-Siglo XXI, 2011.

ARGAYA ROCA, Miguel. Historia de los falangistas en el franquismo. 19 de abril 1934-1 abril 1977. Madrid, Plataforma, 2003.

BERNETTI, Jorge Luis. "De la Falange Española a la Alianza Libertadora Nacionalista y el Movimiento Nacionalista Tacuara”. Pensamiento de los confines, 1 , segundo semestre de 1998.

BLASCO GIL, Yolanda - CORREA BALLESTER, Jorge. "Francisco Javier Conde García, una cátedra de Derecho Político en una España sin constitución". Presente y Futuro de la Constitución Española de 1978, Valencia, Tirant lo Blanch, 2005.

BRANCATO, Sandra. "O Caso Aunós na versão da grande imprensa carioca e do Itamaraty”. Estudos Ibero-Americanos, v. XXXIII, n. 2, dezembro 2007.

${ }^{131}$ Javier MUÑOZ SORO entregó en La invención de la Monarquía democrática (Legitimación política, consenso social y opinión pública ante el reinado de Juan Carlos I), Madrid, CIHDE-UNED, 2006, un reflexivo análisis sobre distintas variantes del falangismo. 
CAMARASA, Jorge. La enviada. El viaje de Eva Perón a Europa. Buenos Aires, Planeta, 1998.

CAMPOS, Esteban, “¿De fascistas a guerrilleros? Una crítica a la historiografía del movimiento nacionalista Tacuara y sus derivas hacia la izquierda peronista en la Argentina”, Revista Tiempo Histórico, N 13, julio-diciembre 2016.

CAÑELLAS MÁS, Antonio (coord.). La tecnocracia hispánica. Ideas y proyecto político en Europa y América. Gijón, Ediciones Trea, 2016.

CARRIÓ, Macarena - FERMANDOIS, Joaquín. "Europa Occidental y el desarrollo chileno, 1945-1973”. Historia, Vol. 36, Santiago, 2003.

CERRANO, Carolina.

- “El filo-peronismo falangista. 1955-1956”. Ayer, No 96, 2014.

- "Diplomacia franquista ante la política argentina, 1955-1962", en FIGALLO, Beatriz (ed.). Desarrollismo, franquismo y neohispanidad. Historias conectadas entre España, América Latina y Argentina. Buenos Aires, Teseo, 2018.

CERRANO, Carolina y PEÑALBA, Mercedes, "La OMU y la Conferencia Internacional de dirigentes universitarios de junio de 1955 vista desde la delegación española del SEU”, Revista electrónica de Fuentes y Archivos, Número 5, 2014.

CSIPKA, Juan Pablo. Los 49 días de Cámpora. Crónica de una primavera rota. Buenos Aires, Sudamericana, 2013.

CUEVAS LANCHARES, Juan Carlos. Los intelectuales y la política en España. Francisco Javier Conde (1908-1974). La legitimación de la dictadura. Tesis doctoral. Universidad Complutense de Madrid, Facultad de Ciencias Políticas y Sociología, 2016.

CUEVILLAS, Fernando de. "Las organizaciones españolas de cultura”, en ÁLVAREZ, Gerardo (coord.). España en la Argentina. Buenos Aires, 1997.

DELGADO GÓMEZ ESCALONILLA, Lorenzo. Imperio de papel. Acción cultural y política exterior durante el primer franquismo. Madrid, CSIC, 1992.

DELGADO GÓMEZ-ESCALONILLA, Lorenzo y Marisa GONZÁLEZ DE OLEAGA. "La dinámica franquismo/oposición en Argentina: un ensayo de interpretación (1936-1950)", en Javier TUSELL, Abdón MATEOS y Alicia ALTED (coords.). La oposición al régimen de Franco. Estado de la cuestión y metodología de la investigación, Tomo I, Vol. 2, Madrid, UNED, 1990.

DELGADO GRANADOS, Patricia. "La Escuela de Estudios Hispanoamericanos de Sevilla: Proceso de configuración de su identidad”. Historia Caribe, Vol. 4, Nro. $12,2007$.

DUPUICH DA SILVA, Monique y SÁNCHEZ DIANA, José María. "Historia de una revista. Consideraciones sobre "Escorial". Boletín de la Institución Fernán González, 44, 165, $2^{\circ}$ sem. 1965.

EIROA SAN FRANCISCO, Matilde.

- Política internacional y comunicación en España (1939-1975). Las cumbres de Franco con Jefes de Estado. Madrid, Ministerio de Asuntos Exteriores, 2009.

- “Acción exterior y propaganda. Las visitas de líderes latinoamericanos a Franco”. Latino@mérica 54, 2012/1. 
ELLWOOD, Sheelagh M. Historia de la Falange Española. Barcelona, Crítica, 2001.

ESCUDERO, María. El Instituto de Cultura Hispánica. Madrid, Mapfre, 1994.

ESPAGNE, Michel, "La notion de transfert culturel”. Revue Sciences/Lettres [En ligne], 1 | 2013, mis en ligne le 01 mai 2012, consulté le 30 septembre 2016.

FARES, María Celina. "Diferencias y convergencias en los hispanismos mendocinos. A propósito del sesquicentenario", en Dossier: El nacionalismo argentino durante la $2^{\circ}$ mitad del siglo XX. historiapolítica.com http://historiapolitica.com/datos/biblioteca/fares2.pdf [Consultado en línea: 1 de abril de 2013].

FAZIO VENGOA, Hugo. "La historia global y su conveniencia para el estudio del pasado y del presente". Historia Crítica, 2009.

FERNÁNDEZ CANTOS, José Luis. “¿Hacia dónde va Iberoamérica?”. Revista de Estudios Políticos, 106, 1959.

FERNÁNDEZ FERNÁNDEZ-CUESTA, Juan Manuel. "La información al servicio de la política exterior. La creación de la oficina de información diplomática, respuesta del franquismo al aislamiento internacional (1945-1950)". Revista Internacional de Historia de la Comunicación, N. ${ }^{\circ}$ 1, Vol. 1, año 2013.

FERRERO BLANCO, María Dolores-EIROA SAN FRANCISCO, Matilde, “1959: los intentos de derrocamiento de las dictaduras de Trujillo, Stroessner y Luis Somoza", Historia Actual On Line, 39 (1), 2016.

FERREYRA, Alejandra Noemí. "La acción propagandística a favor del Franquismo durante la Guerra Civil Española: la actuación de Juan Pablo Lojendio en Buenos Aires (1936-1939)”. Páginas, Vol. 8, N. 16, 2016.

FIGALLO, Beatriz.

- "La Argentina, el Cono Sur y las migraciones políticas tras el derrocamiento de Perón”, Revista Enfoque Social, núm. 2, 2007.

- "De Jiménez de Asúa a Perón: sus exilios como componentes de la política exterior hispano-argentina", Temas de historia argentina y americana, N. ${ }^{0}$ 15, 2009.

- Argentina-España. Entre la pasión y el escepticismo. Buenos Aires, Teseo, 2014.

- "Diplomacia franquista, propaganda y control de los exiliados. La embajada de José María Alfaro en la Argentina, 1955-1971", Épocas, 11, 2015.

- “Sociabilidad y exilio. Perón entre los españoles del franquismo, 1960-1973”. Res Gesta, 53, 2017.

- "Desarrollo y estado de derecho administrativo. El modelo del nuevo hispanismo en la Argentina posperonista", en FIGALLO, Beatriz (ed.). Desarrollismo, franquismo y neohispanidad. Historias conectadas entre España, América Latina y Argentina. Buenos Aires, Teseo, 2018.

- "La Revolución Libertadora y la Guerra Civil Española como mito de origen. Identificaciones y paradojas de dos dictaduras de liberación”, en María Valeria GALVÁN y María Florencia OSUNA (comp.). La "Revolución Libertadora" en el marco de la Guerra Fría. La Argentina y el mundo durante los gobiernos de Lonardi y Aramburu. Rosario, Prohistoria, 2018.

FIGUEREDO CABRERA, Katia. "Carlos Prío Socarrás, Fulgencio Batista, Francisco 
Franco: la escalada hacia una consolidación "fraterna" (1948-1958)". Revista Illes I Imperis, 12, 2009.

FRANK, Robert (dir.). Pour l'histoire des relations internationales. Paris, Presses Universitaires de France, 2012.

FUENMAYOR, Amadeo de - GÓMEZ-IGLESIAS, Valentín - ILLANES, José Luis. El itinerario jurídico del Opus Dei. Historia y defensa de un carisma. Pamplona, Eunsa, 1989.

GALVÁN, María Valeria. "Discursos de los organismos de inteligencia argentinos sobre el Movimiento Nacionalista Tacuara en el marco de la primera Guerra Fría”. Antíteses, vol. 2, n. 4, jul.-dez. de 2009.

GARCÍA, Marcela A. y ITURRIETA, Aníbal. "Perón en el exilio español”. Todo es Historia, Buenos Aires, $\mathrm{N}^{\circ}$ 3134, agosto de 1993.

GIMÉNEZ CABALLERO, Ernesto.

- Asunción, capital de América, Madrid, Ediciones cultura Hispánica, 1971.

- “iYo te invocó Argentina!”. Patria peronista. Órgano de Reafirmación doctrinaria, Año 2, Nro. 17, 1ª Quincena de agosto de 1974.

- Retratos españoles (Bastante parecidos). Barcelona, Planeta, 1985.

- “Crónica del Paraguay”. El País, Madrid, 30 de junio de 1987.

- A fondo. Entrevista por Joaquín Soler Serrano, programa completo, 1977, en Catálogo Cultural de la Mediateca del Centro Cultural de España. en https://www.youtube.com/results?search_query=ernesto+gimenez+caballero ++entrevista++a+fondo [Consultado: 20/07/2018]

GOEBBEL, Michael, La Argentina partida. Nacionalismos y políticas de la historia. Buenos Aires, Prometeo, 2013.

GÓMEZ PÉREZ, Rafael. El franquismo y la Iglesia. Madrid, 1986.

GONZÁLEZ CALLEJA, Eduardo.

- "El servicio exterior de Falange y la política exterior del primer franquismo: consideraciones previas para su investigación”, Hispania, 1994, LIV/1, núm. 186.

- "El Hispanismo autoritario español y el movimiento nacionalista argentino: balance de medio siglo de relaciones políticas e intelectuales (1898-1946)", Hispania, 2007, mayo-agosto, núm. 227.

GONZÁLEZ CALLEJA, Eduardo y LIMÓN NEVADO, Fredes. La Hispanidad como instrumento de combate. Madrid, CSIC, 1988.

GONZÁLEZ DE OLEAGA, Marisa. "Panamericanismo e hispanidad en la política exterior argentina de la Segunda Guerra Mundial. La confrontación política en la creación de identidades colectivas". EIAL, 5, N. 1, 1994.

HARO TEGLEN, Eduardo. "Lo que no fue Giménez Caballero”, El País, Madrid, 16 de mayo de 1988.

HAUSBERGER, Bernd y PANI, Erika. Dossier. Historia Global-Presentación. Historia Mexicana, LXVIII, 1, julio-septiembre, 2018.

INSTITUTO PARAGUAYO DE CULTURA HISPÁNICA. Cuatro años de labor del 
Instituto Paraguayo de Cultura Hispánica (1958-1963). Madrid, Congreso de Instituciones Hispánicas, 1963.

IRIYE, Akira. Global and Transnational History: The Past, Present, and Future. Basingstoke, Palgrave Macmillan, 2013.

JARA HINOJOSA, Isabel. De Franco a Pinochet: el proyecto cultural franquista en Chile 1936-1980. Santiago, Universidad de Chile, 2006.

JARDIEL PONCELA, Eva. Por qué no es usted del Opus Dei. Madrid, Editorial Gráficas Varela, 1974.

JEREZ RIESCO, José Luis. Voluntad de Imperio. La Falange en Argentina. Barcelona, Ediciones Nueva República, 2007.

JIMÉNEZ TORRES, David, Ramiro de Maeztu and England. Imaginaries, realities and repercussions of a Cultural Encounter, Tamesis, Woodbridge, 2016.

JOYEUX-PRUNEL, Béatrice. "Les transferts culturels. Un discours de la méthode”, Hypothèses, 2002, 1.

LAMBERTI, Alejandro. "Iglesia y democracia en la Argentina de los '60 y los '90", en ESTEVEZ, Alejandro M. Proyecto: Estado, Sociedad y cultura democrática en la reforma del estado argentino. Buenos Aires, UCA-Instituto para la Integración del Saber, 2002.

MAEZTU, Ramiro de, Defensa de la Hispanidad, Buenos Aires, Librería Huemul, 1986.

MAINER, José Carlos, selección y prólogo, "Ernesto Giménez Caballero o la inoportunidad", en Ernesto GIMÉNEZ CABALLERO. Casticismo, nacionalismo y vanguardia (Antología, 1927-1935). Madrid, Fundación Santander Central-Hispano, 2005, p. LXVI.

MARCILHACY, David. "La Hispanidad bajo el franquismo. El americanismo al servicio de un proyecto nacionalista", en Xosé M. NÚÑEZ SEIXAS y Stéphane MICHONNEAU (eds.). El imaginario nacionalista español en el franquismo. Madrid, Casa de Velázquez, 2014.

MESA, Roberto, ed. Jaraneros y alborotadores. Documentos sobre los sucesos estudiantiles de febrero de 1956 en la Universidad Complutense de Madrid. Madrid, UCM, 2006, 2da. Edición.

MINARDI, Adriana.

- "El franquismo a la luz de sus metáforas". Cultura, Lenguaje y representación, Vol. 9, 2011.

- "Devociones de lo nacional en la obra de Ernesto Giménez Caballero: Ensayo, genericidad e imagen”. Anuario brasileño de estudios hispánicos, N. ${ }^{\circ}$ 26, 2016.

MONFERRER CATALÁN, Luis. Odisea en Albión: los republicanos españoles exiliados en Gran Bretaña 1936-1977. Madrid, Ediciones de la Torre, 2007.

MORENO CANTANO, Antonio César (coord.). Cruzados de Franco. Propaganda y diplomacia en tiempos de guerra (1936-1945). Gijón, Trea, 2013.

MORENTE, Francisco. "Rafael Sánchez Mazas y la esencia católica del fascismo español”, en Miguel Á. RUIZ-CARNICER, editor. Falange. Las culturas políticas del fascismo en la España de Franco (1936-1975). Zaragoza, 
Institución Fernando el Católico, 2013.

MUNS ALBUIXECH, Joaquín. "España y el Fondo Monetario Internacional (FMI)". Economistas, $\mathrm{N}^{\circ}$ 90, 2001.

MUÑOZ SORO, Javier.

- "Joaquín Ruiz-Giménez o el catolicismo total (Apuntes para una biografía política e intelectual hasta 1963)”. Pasado y Memoria. Revista de Historia Contemporánea, 5 , 2006.

- La invención de la Monarquía democrática (Legitimación política, consenso social y opinión pública ante el reinado de Juan Carlos I). Madrid, CIHDE-UNED, 2006.

ORELLA, José Luis. "El origen de la derecha tecnocrática española y sus consecuencias", en Ernesto BOHOSLAVSKY-Olga ECHEVERRÍA (comps.). Las derechas en el Cono Sur, siglo XX. Actas del tercer taller de discusión. Los Polvorines, 2013.

PARDO SANZ, Rosa María.

- "Hispanoamérica en la política nacionalista, 1936-1939". Espacio, Tiempo y Forma, Serie V, H. Contemporánea, t. V, 1992.

- "De puentes y comunidades: balance historiográfico sobre las relaciones con América Latina”, en Lorenzo DELGADO GÓMEZ-ESCALONILLA, Ricardo Martín de la GUARDIA y Rosa PARDO SANZ (eds.). La apertura internacional de España. Entre el franquismo y la democracia, 1953-1986. Madrid, Ediciones Silex, 2016.

PÉREZ MONTFORT, Ricardo. Hispanismo y Falange. Los sueños imperiales de la derecha española y México. México, FCE, 1992.

POZO REDONDO, Felipe del. "Un aspecto de la estrategia cultural franquista hacia América Latina: la Universidad Hispanoamericana de La Rábida (1943-1974)”, en Francisco A. RUBIO DURÁN-R. DELIBES MATEOS (eds.). Espacio y poder en América Latina. Actores y escenarios históricos en los contextos de dominación. Sevilla, Aconcagua Libros, 2010.

PULPILLO LEIVA, Carlos. Orígenes del franquismo: la construcción de la nueva España (1936-1941). Tesis doctoral, Universidad Rey Juan Carlos, Madrid, 2013.

QUIJADA, Mónica. Aires de República, Aires de Cruzada. La Guerra Civil Española en la Argentina. Barcelona, Sendai Ediciones, 1991.

RAMOS, José Ignacio. Biografía de mi entorno. Nostalgias, recuerdos, testimonios. Buenos Aires, Legasa, 1984.

REIN, Raanan. "Los hombres detrás del Hombre: la segunda línea de liderazgo peronista”. Araucaria. Revista Iberoamericana de Filosofia, Política y Humanidades, N. ${ }^{0}$ 19, primer semestre 2008.

RIQUER, Borja de, "La dictadura de Franco", en Josep FONTANA-Ramón VILLARES, Historia de España. Volumen 9. Madrid, Critica, 2010.

RODRÍGUEZ ALCALÁ, Guido. Ideología autoritaria. Asunción, RP Ediciones 1987.

RODRÍGUEZ-LAGO, José Ramón. "La clave Cortesi. La política vaticana en la 
República Argentina (1926-1936)”. Historia Contemporánea, 55, 2017.

RODRÍGUEZ PUÉRTOLAS, Julio.

- Literatura fascista española. Volumen I, Historia. Madrid, 1986.

- Historia de la literatura fascista española. I. Madrid, Akal, 2008.

ROSETTI, Mariana. "La polémica del Meridiano Intelectual de 1927. La lucha por el cauce de las corrientes intelectuales”. Lexis, Vol. XXXVI (1), 2012.

RUBINZAL, Mariela. El nacionalismo frente a la cuestión social en Argentina [19301943]: Discursos, Representaciones y prácticas de las derechas sobre el mundo del trabajo [en línea]. Tesis doctoral. Universidad Nacional de La Plata. Facultad de Humanidades y Ciencias de la Educación. Disponible en: http://www.memoria. fahce.unlp.edu.ar/tesis/te.450/te.450.pdf,

RUIZ NESTOSA, Jesús. “Contra el olvido”. ABC Color, Asunción, 7 de marzo de 2014.

SANCHEZ RECIO, Glicerio (coord.). La Internacional Católica. Pax Romana en la política europea de posguerra. Madrid, Biblioteca Nueva, 2005.

SAZ, Ismael. "Franco, ¿caudillo fascista? Sobre las sucesivas y contradictorias concepciones falangistas del caudillaje franquista”. Historia y Política, núm. 27, enero-junio 2012.

SCAVONE YEGROS, Ricardo, "Introducción R. Antonio Ramos y los estudios históricos de las relaciones entre el Paraguay y el Brasil”, en R. ANTONIO RAMOS, La Independencia del Paraguay y el Imperio del Brasil, Brasilia, Fundación Alexandre de Gusmão, 2016.

SEIFERHELD, Alfredo. Nazismo y fascismo en el Paraguay. Vísperas de la II Guerra Mundial. Gobiernos de Rafael Franco y Félix Paiva. 1936-1939. Asunción, Editorial Histórica, 1985.

SELVA ROCA DE TOGORES, Enrique.

- Ernesto Giménez Caballero. Entre la vanguardia y el fascismo. Valencia, Pre-Textos, 2000.

- "La insólita aventura de Ernesto Giménez Caballero". Revista Universitaria de Historia Militar, Volumen 7, número 13, 2018.

SESMA LANDRIN, Nicolás.

- Camino a la institucionalización. La pugna entre Falange y los sectores en torno al proceso de reforma administrativa de finales de los años cincuenta. Seminario de Historia, Instituto Universitario José Ortega y Gasset-Curso 2008-2009, Madrid, Documento de trabajo 2009/2.

- "Franquismo, ¿Estado de Derecho? Notas sobre la renovación del lenguaje político de la dictadura durante los años 60". Pasado y Memoria. Revista de Historia Contemporánea, 5, 2006.

TATEISHI, Hirotaka. "Zacarías de Vizcarra y la vocación de América: Apuntes sobre la Hispanidad y el nacional-catolicismo". The Mediterranean Studies Group Hitotsubashi University, 2004-03.

TESSADA SEPÚLVEDA, Vanessa.

- "Fronteras de la Comunidad Hispánica de Naciones. El aporte de la Sección Femenina 
de Falange y su proyección en Latinoamérica”, ILCEA [En ligne], 18 | 2013, mis en ligne le 11 juillet 2013, consulté le 29 avril 2016. URL: http://ilcea.revues.org/2068

- Las estrategias de proyección internacional de la Sección Femenina española hacia Latinoamérica y su recepción en Chile (1937-1977), Tesis doctoral, Universidad de Valladolid, 2017.

THOMÀS, Joan María. Lo que fue la Falange: La Falange y los falangistas de José Antonio, Hedilla y la Unificación. Franco y el fin de la Falange Española de las JONS. Barcelona, Plaza \& Janés, 1999.

TROIANI, Osiris. "España: “Qué vendrá después de Franco?”. Primera Plana, № 77 , Buenos Aires, 28 de abril de 1964.

VÁZQUEZ DE PRADA, Andrés. El fundador del Opus Dei. III. Los caminos divinos de la tierra. Madrid, Rialp, 2003.

VIZCARRA, Zacarías de. "Origen del nombre, concepto y fiesta de la hispanidad". El Español, Madrid, 7 de octubre de 1944.

WEINSTEIN, Barbara. "Pensando la historia más allá de la nación: la historiografía de América Latina y la perspectiva transnacional". Aletheia, 2013, 3, $\mathrm{n}^{\circ} 6$.

YAZBEK, Susana y QUEIPO RIAVITZ, Anandí. "La España franquista como modelo de organización social para el sindicalismo argentino. El caso de la Federación Sindicatos Unidos Petroleros del Estado (SUPE)". XIV Jornadas Interescuelas/Departamentos de Historia, Mendoza, 2013.

ZAFRILLA TOBARRA, Ricardo. Universidades laborales. Un proyecto educativo falangista para el mundo obrero (1955-1978): aproximación histórica. Cuenca, Universidad de Castilla-La Mancha, 1998.

ZUBILLAGA, Carlos. Una historia silenciada. Presencia y acción del falangismo en Uruguay (1936-1955). Montevideo, Ediciones Cruz del Sur, 2015.

ZULETA ÁLVAREZ, Enrique. "España y el nacionalismo argentino". Cuadernos del Sur, $\mathrm{N}^{\circ}$ 23/24, 1993.

\section{Fuentes inéditas}

Archivo del Ministerio de Asuntos Exteriores de España (Palacio de Santa Cruz, Madrid), Sección Archivo Renovado (Serie R), Fondos: Embajada de España en la Argentina, 1955-1971; Notas Informativas, 1966; Viajes del ministro López Bravo, 1971.

\section{Prensa}

$A B C$, Madrid

$A B C$, Asunción

El Día, La Plata

El Español, Madrid

El País, Madrid

Informaciones, Madrid

La Prensa, Buenos Aires

La Vanguardia Española, Barcelona 
Última Hora, Asunción 